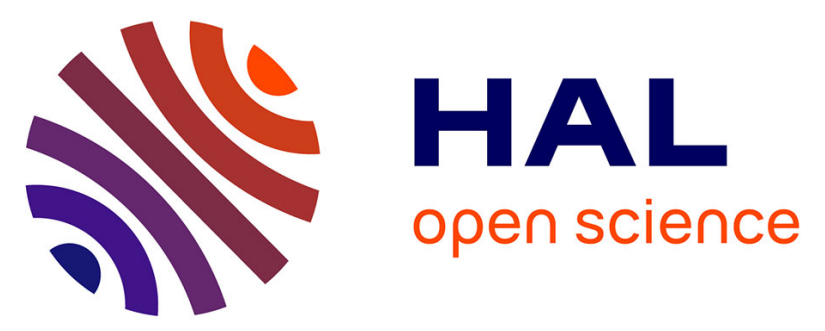

\title{
Shallow creep along the 1999 Izmit earthquake rupture (Turkey) from GPS and high temporal resolution interferometric synthetic-aperture radar data (2011-2017)
}

Gokhan Aslan, Cécile Lasserre, Ziyadin Çakir, Semih Ergintav, Seda Cetin, Ugur Dogan, Roger Bilham, Francois Renard

\section{To cite this version:}

Gokhan Aslan, Cécile Lasserre, Ziyadin Çakir, Semih Ergintav, Seda Cetin, et al.. Shallow creep along the 1999 Izmit earthquake rupture (Turkey) from GPS and high temporal resolution interferometric synthetic-aperture radar data (2011-2017). Journal of Geophysical Research: Solid Earth, 2019, 124 (2), pp.2218-2236. 10.1029/2018JB017022 . hal-02058155

\section{HAL Id: hal-02058155 \\ https://hal.science/hal-02058155}

Submitted on 1 Sep 2021

HAL is a multi-disciplinary open access archive for the deposit and dissemination of scientific research documents, whether they are published or not. The documents may come from teaching and research institutions in France or abroad, or from public or private research centers.
L'archive ouverte pluridisciplinaire HAL, est destinée au dépôt et à la diffusion de documents scientifiques de niveau recherche, publiés ou non, émanant des établissements d'enseignement et de recherche français ou étrangers, des laboratoires publics ou privés. 


\section{RESEARCH ARTICLE 10.1029/2018JB017022 \\ Key Points: \\ - Two decades after the Izmit Earthquake, the central segment of the rupture is still creeping at a rate of up to $\sim 8 \mathrm{~mm} /$ year \\ - A 1-month transient accelerating creep event with 10-mm amplitude at the surface is detected, consistently from three independent InSAR time series \\ - A subsidence of the hanging wall of the Golcuk normal fault is observed for the first time from high spatial resolution InSAR data and may be related to shallow afterslip}

Supporting Information:

- Supporting Information S1

Correspondence to:

G. Aslan,

gokhan.aslan@univ-grenoble-alpes.fr

Citation:

Aslan, G., Lasserre, C., Cakir, Z., Ergintav, S., Özarpaci, S., Dogan, U., et al. (2019). Shallow creep along the 1999 Izmit earthquake rupture

(Turkey) from GPS and high temporal resolution interferometric synthetic aperture radar data (2011-2017) Journal of Geophysical Research: Solid Earth, 124, 2218-2236. https://doi.org/ 10.1029/2018JB017022

Received 14 NOV 2018 Accepted 31 JAN 2019 Accepted article online 4 FEB 2019 Published online 27 FEB 2019

\section{Shallow Creep Along the 1999 Izmit Earthquake Rupture (Turkey) From GPS and High Temporal Resolution Interferometric Synthetic Aperture Radar Data (2011-2017)}

\author{
Gokhan Aslan $^{1,2}$ (D) Cécile Lasserre $^{3}$ (D), Ziyadin Cakir ${ }^{4}$ (D), Semih Ergintav ${ }^{5}$ (D), Seda Özarpaci ${ }^{6}$ (D), \\ Ugur Dogan $^{6}$, Roger Bilham ${ }^{7}$ (D), and François Renard ${ }^{1,8}$ (iD)
}

${ }^{1}$ Université Grenoble-Alpes, Université Savoie Mont Blanc, CNRS, IRD, IFSTTAR, ISTerre, Grenoble, France, ${ }^{2}$ Eurasia Institute of Earth Sciences, ITU, Maslak, Istanbul, Turkey, ${ }^{3}$ Université de Lyon, UCBL, ENSL, CNRS, LGL-TPE,

Villeurbanne, France, ${ }^{4}$ Department of Geological Engineering, ITU, Maslak, Istanbul, Turkey, ${ }^{5}$ Department of Geodesy, Kandilli Observatory and Earthquake Research Institute, Bogazici University, Istanbul, Turkey, ${ }^{6}$ Department of Geomatic Engineering, Yildiz Technical University, Istanbul, Turkey, ${ }^{7}$ CIRES and Department of Geological Sciences, University of Colorado Boulder, Boulder, CO, USA, ${ }^{8}$ The Njord Centre, PGP, Department of Geosciences, University of Oslo, Oslo, Norway

Abstract Characterizing the spatiotemporal evolution of creep is essential to constrain fault slip budget and understand creep mechanism. Studies based on interferometric synthetic aperture radar and Global Positioning System (GPS) satellite observations until 2012 have shown that the central segment of the 17 August $1999 M_{w}$ 7.4 Izmit earthquake on the North Anatolian Fault began slipping aseismically following the event. In the present study, we combine new interferometric synthetic aperture radar time series, based on TerraSAR-X and Sentinel 1A/B radar images acquired over the period 2011-2017, with near-field GPS measurement campaigns performed every 6 months from 2014 to 2016 . The mean velocity fields reveal that creep on the central segment of the 1999 Izmit fault rupture continues to decay, more than 19 years after the earthquake, in overall agreement with models of postseismic afterslip decaying logarithmically with time for a long period of time. Along the fault section that experienced supershear velocity rupture during the Izmit earthquake creep continues with a rate up to $\sim 8 \mathrm{~mm}$ /year. A significant transient accelerating creep is detected in December 2016 on the Sentinel-1 time series, near the maximum creep rate location, associated with a total surface slip of $10 \mathrm{~mm}$ released in 1 month only. Additional analyses of the vertical velocity fields show a persistent subsidence on the hanging wall block of the Golcuk normal fault that also ruptured during the Izmit earthquake. Our results demonstrate that afterslip processes along the North Anatolian Fault east-southeast of Istanbul are more complex than previously proposed as they vary spatiotemporally along the fault.

\section{Introduction}

\subsection{Fault Creep and Seismic Potential}

A better understanding of seismic and aseismic slip behaviors of active faults is a crucial challenge for the estimation of seismic hazard (Avouac, 2015). While most active faults release abruptly the strain that has accumulated over long time, some other faults slip continuously or transiently (e.g., Burford \& Harsh, 1980; Thatcher, 1979). Aseismic slip occurring within or around the seismogenic zone along continental faults is usually referred to as creep. Studies over the last decades show that aseismic slip occurs at varying depths and rates in the seismogenic crust and hence creeping faults also generate earthquakes but usually less frequently and/or of smaller size than the fully locked fault segments (Cetin et al., 2014; Jolivet et al., 2013; Kaneko et al., 2013; Maurer \& Johnson, 2014; Schmidt et al., 2005). Therefore, determining the relative budget of seismic and aseismic slips, as well as their spatiotemporal interactions and relationship with fault properties, is crucial for determining the seismic potential of active faults (Avouac, 2015; Bürgmann et al., 2000; Bürgmann \& Thatcher, 2013; Harris, 2017). Aseismic slip can occur with various temporal behaviors: it can be steady (e.g., Fialko, 2006; Motagh et al., 2007), as observed during the interseismic period, or transient (e.g., Hayes et al., 2014), either triggered by a major earthquake and decaying with time (postseismic relaxation known as afterslip, e.g., Lienkaemper et al., 2001) or spontaneously generated by processes still 
poorly understood. Frictional properties, fault geometry and lithology, as well as pore fluid pressure variations were proposed to explain creep behavior (Avouac, 2015; Bürgmann, 2018). For example, the presence of clay-rich gouges and high fluid pressure appear as key factors for the presence of creep (Carpenter et al., 2011, Kaduri et al., 2017, 2018). Recent development and widespread use of advanced space-based techniques, particularly interferometric synthetic aperture radar (InSAR), has revealed that steady or transient surface creep behavior along major continental faults is more common than previously thought. A recent review by Harris (2017) discussed the earthquake potential of shallow creeping continental faults using worldwide data. Reported cases include the Hayward fault (Savage \& Lisowski, 1993; Schmidt et al., 2005), the Supersitition Hills fault (Bilham, 1989; Wei et al., 2009), and the Central San Andreas Fault in California (De Michele et al., 2011, Jolivet, Candela, et al., 2015, Khoshmanesh \& Shirzaei, 2018), the Longitudinal Valley fault in Taiwan (Champenois et al., 2012; Thomas et al., 2014), the Ismetpasa segment of North Anatolian Fault in Turkey (Ambraseys, 1970; Bilham et al., 2016; Cakir et al., 2005; Cetin et al., 2014; Kaneko et al., 2013; Rousset et al., 2016), the Izmit and Marmara segment of the North Anatolian Fault (Cakir et al., 2012; Ergintav et al., 2014; Hussain et al., 2016), the Haiyuan fault in China (Jolivet et al., 2012, 2013, Jolivet, Simons, et al., 2015), the El-Pilar fault in Venezuela (Jouanne et al., 2011, Pousse-Beltram et al., 2016), and the Chaman fault in Pakistan (Barnhart, 2017; Fattahi \& Amelung, 2016). These studies show that the spatial patterns (rate and rate-change distribution along strike and with depth) vary significantly. These variations may be exploited to develop a better understanding of aseismic slip processes and their relationships with seismic hazard (Avouac, 2015).

\subsection{Postseismic Creep Along the North Anatolian Fault: Previous Measurements and Objectives of the Present Study}

The Anatolian plate is bounded by the right-lateral North Anatolian Fault and the left-lateral East Anatolian Fault to the north and east-southeast of Turkey, respectively. This plate is moving westward due to the convergence of the Arabian and Eurasian plates. The 1600-km-long North Anatolian Fault is a major continental strike-slip fault, known as one of the most active faults in the eastern Mediterranean region, with an average slip rate of $24 \pm 2 \mathrm{~mm} /$ year (Reilinger et al., 2006). This right-lateral fault has ruptured between 1939 and 1999 in a sequence of eight $M>7$ earthquakes, with a westward migration that started near Erzincan in the east and reached the Sea of Marmara in the west. This migration has been explained by the cumulative Coulomb stress transfer during and between successive earthquakes along strike (Stein et al., 1997). Assessment of seismic hazard in the Marmara region suggests that a large and destructive earthquake $(M>7)$ may occur with a probability of $>35-70 \%$ in the next 30 years under the Sea of Marmara, $20 \mathrm{~km}$ south of Istanbul (Armijo et al., 2005; Parsons, 2004).

The Ismetpasa and Izmit segments of the North Anatolian Fault are the two sections inland that exhibit shallow aseismic creep in the uppermost few kilometers of the upper crust. Creep is also inferred below the Marmara Sea from the study of microseismicity and geodesy (Ergintav et al., 2014; Schmittbuhl et al., 2016). Based on the observations of the slow displacement of a wall at the train station of Ismetpasa in the period 1957-1969, and railway maintenance reports, the fault creeping behavior at Ismetpasa was first documented by Ambraseys (1970), a decade after the first observation of this phenomenon on the San Andreas Fault (Steinbrugge et al., 1960). Various measurements afterward (Global Positioning System [GPS], InSAR, light detection and ranging [LIDAR], creepmeter, and field observations) allowed to better characterize the spatiotemporal properties of creep along the Ismetpasa fault section (Aytun, 1982; Bilham et al., 2016; Cakir et al., 2005; Cetin et al., 2014; Deniz et al., 1993; Eren, 1984; Kaduri et al., 2017; Kaneko et al., 2013; Ozener et al., 2012; Rousset et al., 2016). All studies combined show that the creep rate is decaying with time following the 1944 rupture (Cetin et al., 2014), so that creep has been interpreted as postseismic relaxation. Gouges formed within the fault zone rocks contain low friction minerals that could explain the creeping behavior of the fault (Kaduri et al., 2017).

The Izmit creeping section of the North Anatolian Fault was the locus of the $M_{w} 7.4$ Izmit earthquake on 17 August 1999. This earthquake ruptured $145 \mathrm{~km}$ of the western section of this fault, along five segments separated by releasing stepovers. The rupture extended from Düzce in the east to the submarine segment of the Hersek delta in the Marmara Sea in the west (Barka et al., 2002; Figure 1). The 1999 Izmit rupture propagated at a supershear rupture velocity $(5 \mathrm{~km} / \mathrm{s})$ over a large part of the fault zone (Bouchon et al., 2001). This earthquake was followed by the $M_{w} 7.2$ Düzce earthquake 86 days after, which ruptured a $45-\mathrm{km}$ - 


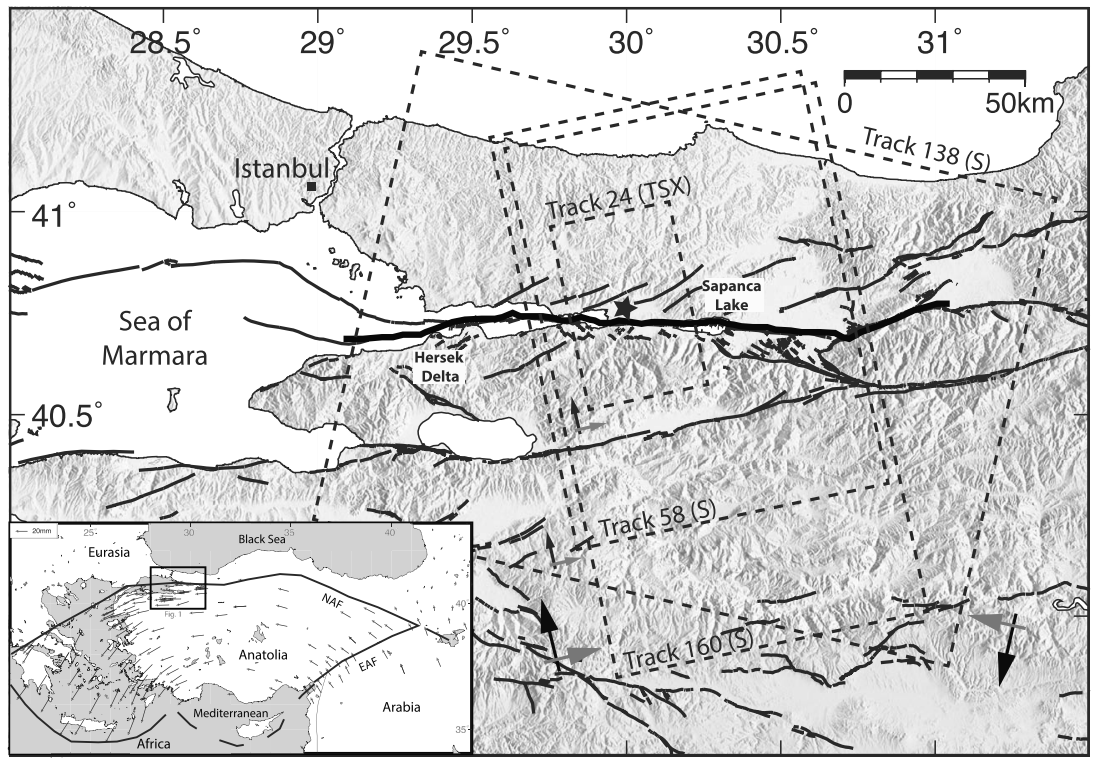

Figure 1. Tectonic setting and interferometric synthetic aperture radar data coverage. Inset map shows relative plate motions, with Global Positioning System vectors in a Eurasia fixed reference frame (Reilinger et al., 2006). The study area along the North Anatolian Fault is indicated with a black rectangle. Dashed rectangles in main figure outline the location of processed radar images, with track numbers indicated (S: Sentinel 1A/B, TSX: TerraSAR-X). Gray and black arrows show line-of-sight and flight directions of the satellites, respectively. Shaded topography is from Shuttle Radar Topography Mission. The 17 August 1999 Izmit surface rupture trace (Barka et al., 2002) and other active faults (Emre et al., 2013) are drawn with bold black and thin black lines, respectively. The black star indicates the epicenter of the Izmit earthquake.

long segment of the North Anatolian Fault (Cakir, de Chabalier, et al., 2003; Konca et al., 2010). The Izmit earthquake modified the stress distribution on this fault and played an important role in the occurrence of the Düzce event by promoting stress change and postseismic deformation transients (Cakir, Barka, et al., 2003; Hubert-Ferrari et al., 2000).

First observation of creep along the central segment of the Izmit rupture was documented by Cakir et al. (2012), using GPS and a Persistent Scatterer Interferometry (PSI) analysis of 24 ERS SAR images, acquired between 1992 and 1999, and 36 Envisat SAR images, acquired between 2003 and 2009. These authors investigated pre-earthquake and postearthquake surface deformation along the supershear segment of the Izmit rupture and concluded that, as no creep was measured before the 1999 Izmit earthquake, the surface creep was related to postseismic afterslip, with a rate of 8-10 mm/year. Using GPS data and additional Envisat images acquired between 2003 and 2012, from both ascending and descending orbits which allowed to better separate the horizontal and vertical components of creep, Hussain et al. (2016) reported that aseismic slip was confined to shallow depths $(<10 \mathrm{~km})$ and confirmed its decaying creep rate through time. Their results showed that creep extends spatially from the Gulf of Izmit in the west to the east of Sapanca Lake in the east, with an average horizontal, fault-parallel slip rate of $6 \mathrm{~mm} /$ year and a maximum rate of $11 \pm 2 \mathrm{~mm} /$ year, which is nearly $40 \%$ of the annual tectonic loading rate (Hussain et al., 2018; Reilinger et al., 2006). Such slip deficit implies that elastic strain is still being accumulated on the fault along the Izmit section. Different models have been proposed to explain such postseismic deformation after the 1999 Izmit earthquake. Postseismic slip partly consists of afterslip on the fault plane and could be controlled by the frictional properties of the fault zone after a stress perturbation (Marone, 1998). Using a three-dimensional viscoelastic finite element method, Hearn et al. (2009) and Wang et al. (2009) proposed that the postseismic deformations in the region of the 1999 Izmit and Düzce events were the result of a combination of shallow afterslip and viscoelastic relaxation of lower crust and/or upper mantle.

The most recent radar satellite constellations, with greater spatial and temporal resolution, offer the opportunity to refine the measurement of aseismic slip phenomena and to further understand the underlying processes. We demonstrate here the contribution of high-resolution TerraSAR-X and Sentinel-1 InSAR data sets 


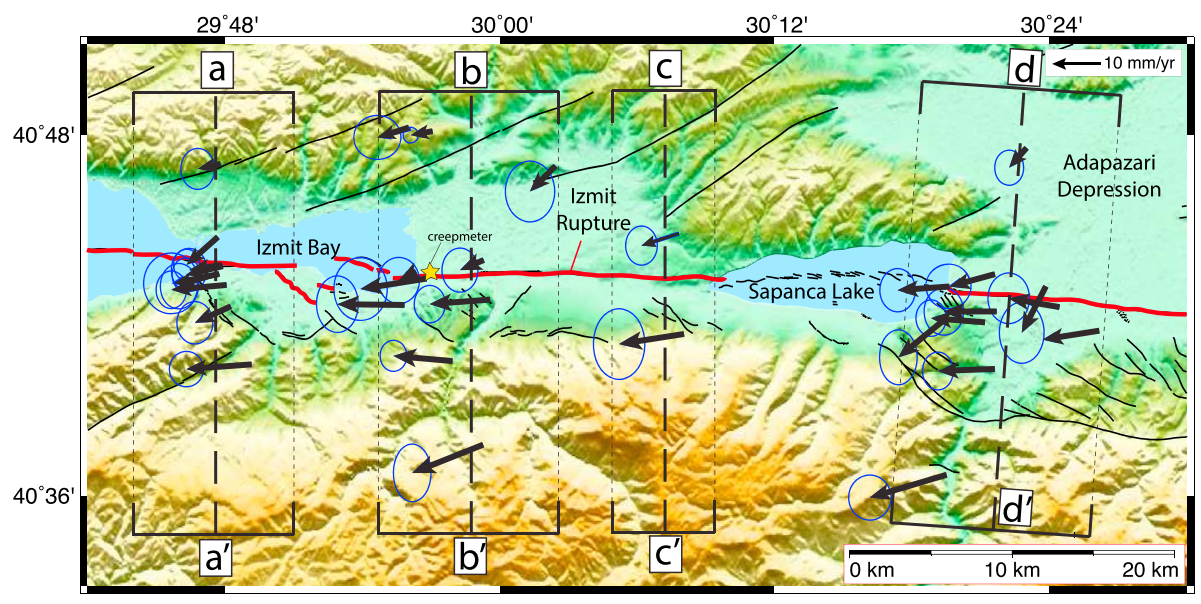

Figure 2. GPS velocities and 95\% confidence ellipses for the period 2014-2016 plotted in Eurasia fixed reference frame (defined as in Reilinger et al., 2006). GPS profiles $\mathrm{aa}^{\prime}, \mathrm{bb}^{\prime}, \mathrm{cc}^{\prime}$, and $\mathrm{dd}^{\prime}$ are projected onto InSAR profiles shown in Figures 7 and 10 for joint GPS/InSAR inversion. Yellow star indicates the location of the creep meter used in this study. GPS = Global Positioning System; InSAR = interferometric synthetic aperture radar.

to better characterize in space and time the aseismic slip along the Izmit section of the North Anatolian Fault.

\section{GPS Data and Processing}

To complement InSAR Sentinel-1 data (section 3) in modeling the most recent creep rate (section 4.3) along the Izmit section of the North Anatolian Fault, we used GPS data that we acquired from 2014 to 2016 during five campaigns ( 1 every 6 months) along near-field zone. Figure 2 shows the corresponding GPS velocity field for the study area. Details on GPS sites, velocities, and associated uncertainties are provided in Table S1 in the supporting information. GPS data were processed using the GAMIT/GLOBK (V10.6) software developed by MIT (Herring et al., 2015), following the processing strategy in Ergintav et al. (2009).

\section{InSAR Data and Methodology}

\subsection{Multisensor InSAR Data Set}

To monitor the surface creep behavior along the Izmit rupture in the period 2011-2017, we processed radar images from two different satellites and three different viewing geometries. In order to observe the deformation pattern at high spatial resolution, we used one X-band data set of 32 TerraSAR-X images, acquired in StripMap mode along ascending orbit (track 24) between 2011 and 2015. We also used three C-band data sets with 275 images in total, from three tracks of the Sentinel 1A/B satellites operated by the European Space Agency, acquired in TOPS mode along descending and ascending orbits (Tracks 58 [Asc], 160 [Asc], and 138 [Dsc]; Figures 1 and 3). Data span the period from October 2014 until July 2017. The 25-km-long Izmit-Sapanca Lake segment of the 1999 Izmit rupture is entirely covered by all tracks (Figure 1). The temporal resolution of the Sentinel 1 data set increased from 12 days until October 2016 to 6 days after it, after the launch (April 2016) and starting of operational phase of Sentinel 1B (Figure 3).

\subsection{PS-InSAR Processing}

TerraSAR-X (TSX) interferograms were constructed using the DORIS software developed by The Delft Institute of Earth Observation and Space Systems at Delft University of Technology (Kampes et al., 2003). Sentinel-1 interferograms were processed with GMTSAR software (Sandwell et al., 2011). In both cases, we used the Shuttle Radar Topography Mission 3-arcsec ( 90-m spatial resolution) digital elevation model for correcting topographic contributions to the radar phase. The choice of the master images for each track has been made so as to minimize the spatial and temporal baselines. For the sake of consistency between the three Sentinel-1 tracks, the master image is chosen in November 2015 for all tracks. For the TSX track, it is chosen in July 2014 (Figure 3). 


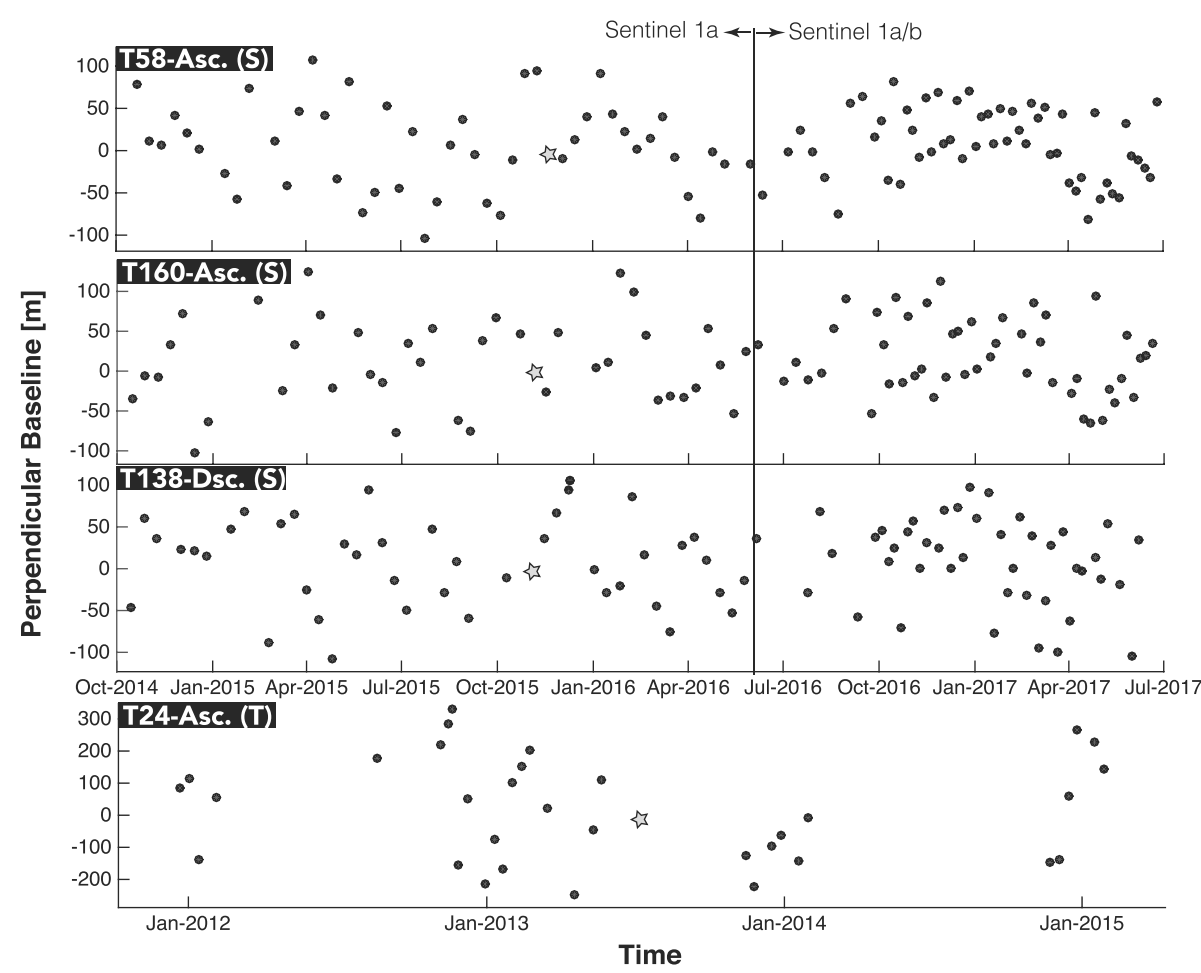

Figure 3. Plot of baseline versus time of synthetic aperture radar (SAR) images for different tracks and satellites (S: Sentinel-1, T: TerraSAR-X), used to compute displacement fields and time series. Black dots indicate SAR images, and gray stars indicate the master image chosen for time series analyses.

Following interferogram processing, we used the permanent scatterers InSAR (PS-InSAR) technique to compute the displacement time series of each stable PS pixel (PS) in the study area, based on a single master network and the Stanford Method for Persistent Scatterers (StaMPS; Hooper, 2008; Hooper et al., 2012). This PS-InSAR technique is an advanced method used to monitor surface deformation caused by tectonic or anthropogenic activities. It exploits the radar return signal reflected from persistent scatterers (phase-stable targets) such as rooftops, large rock outcrops, bridges, or motorways (Ferretti et al., 2001). It allows monitoring subtle and slow deformation signal, mitigating errors due to atmosphere, digital elevation model, and orbital inaccuracies using spatial and temporal filtering. StaMPS uses both amplitude and phase information to identify PS points. In an initial step, the selection of PS points is performed based on their noise characteristics, using an amplitude analysis. The amplitude dispersion criterion is defined by $D_{\mathrm{Amp}}=\left(\sigma_{\mathrm{Amp}} / m_{\mathrm{Amp}}\right)$ where $\sigma_{\mathrm{Amp}}$ and $m_{\mathrm{Amp}}$ are the standard and mean deviation of the amplitude in time, respectively (Ferretti et al., 2001). In the present study, we selected a threshold value of 0.42 for $D_{\mathrm{Amp}}$, which minimizes the random amplitude variability and eliminates highly decorrelated pixels in some areas covered with vegetation, agricultural fields or snow. Once coherent PS points have been selected based on this amplitude analysis, the PS selection is refined by phase analysis in a series of iterations, which allows the detection of stable pixels even with low amplitude. The next steps of the StaMPS processing include correction of the residual topographic component and 3-D unwrapping of the PS phase both spatially and temporally.

Unwrapped interferograms after PS selection were corrected from stratified tropospheric delays using the freely available Toolbox for Reducing Atmospheric InSAR Noise (Bekaert et al., 2015), based on the ERAInterim (ERA-I) global atmospheric model. Corrected interferograms were then used to compute mean velocity fields in StaMPS. The effect of such corrections is shown on the Figure S1 in the supporting information.

Finally, we transformed the mean velocity fields of each track into an Eurasia-fixed GPS reference frame, following the procedure described by Hussain et al. (2016), using the GPS velocities around the 1999 Izmit rupture published by Reilinger et al. (2006). These GPS velocities are derived from pre-1999 earthquake observations (i.e., they do not include coseismic or postseismic deformation). 


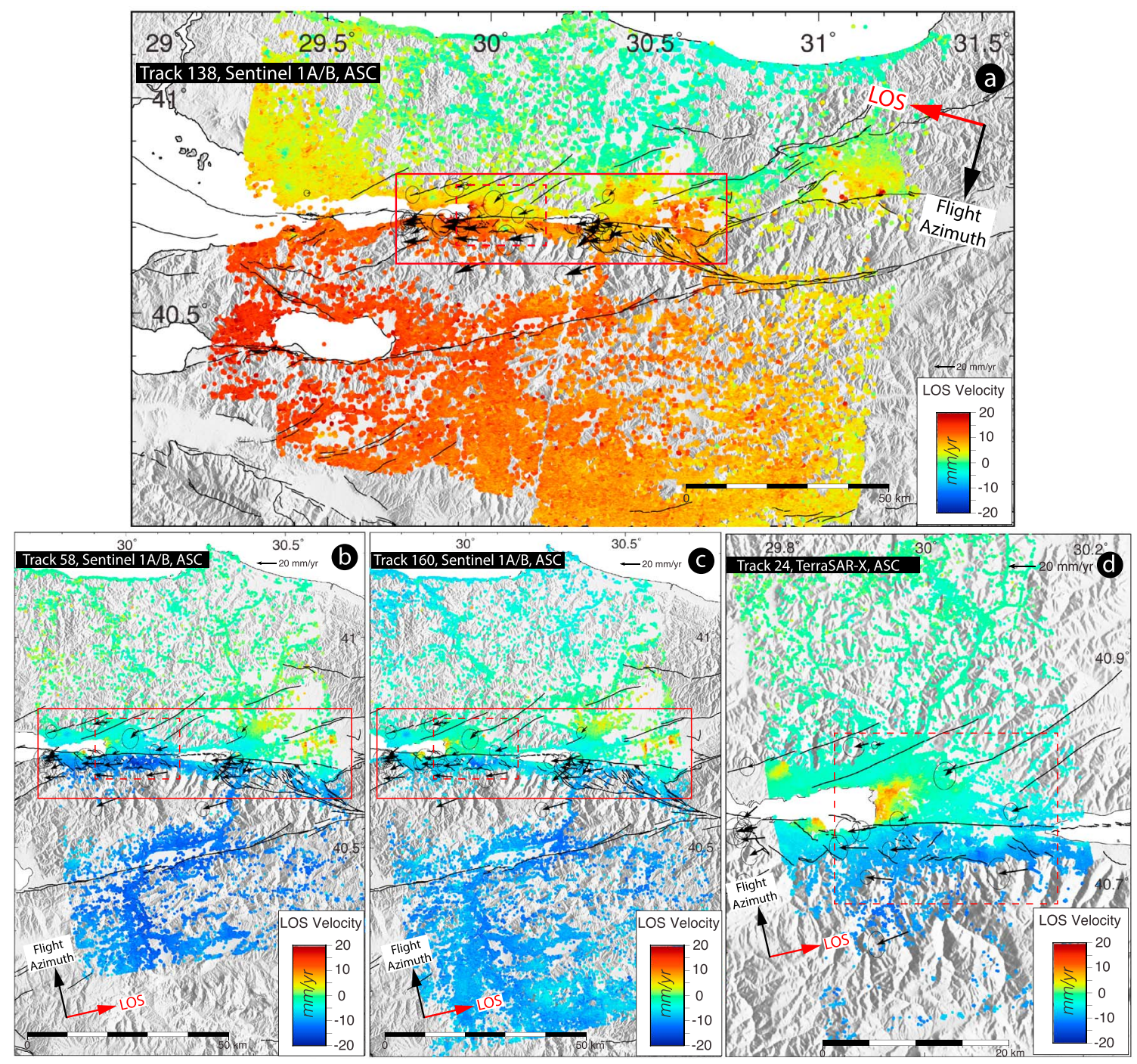

Figure 4. Mean line-of-sight (LOS) velocity fields for the period 2014-2017, from Sentinel 1A/B descending track 138 (a), ascending tracks 58 (b) and 160 (c), and for the period 2011-2015 from TerraSAR-X ascending track 24 (d), obtained from permanent scatterer-interferometric synthetic aperture radar time series analysis, and expressed in a Eurasia-fixed reference frame. Negative velocities (cold colors) represent motion of the ground toward the satellite and positive velocities (warm colors) represent motion away from the satellite. Dashed-line red boxes indicate the coverage of close-up views of average LOS velocity fields shown in Figure 5. Plain-line red boxes highlight the region selected for decomposing horizontal and vertical velocity fields along the fault in Figures $8 \mathrm{a}$ and $8 \mathrm{~b}$. Black lines indicate active faults in the region (Emre et al., 2013). Black vectors show post-2014, Global Positioning System horizontal velocities from Figure 2.

\section{Results}

\subsection{Mean Line-of-Sight Velocity Fields}

Figures 4 and 5 show the mean line-of-sight velocity fields calculated from PS-InSAR time series analysis along the Izmit earthquake rupture with negative velocities (cold colors) representing motion of the ground toward the satellite and positive velocities (warm colors) motion away from the satellite. The change of motion direction across the NAF is attested by the warm/cold color contrast across the fault. Considering the different geometries of data acquisition (i.e., ascending or descending), it is consistent with a right-lateral slip displacement on the fault, due to the westward movement of the Anatolian plate relative to the Eurasian plate. All line-of-sight velocity maps show a very sharp velocity gradient along the central section of the Izmit rupture, in particular between the Izmit Bay and the Sapanca Lake (Figures 2 and 5), which constitutes evidence for shallow creep (Bürgmann et al., 2002; Cakir et al., 2012). East of Sapanca Lake, the creep signal seems to disappear, which differs from previous InSAR results derived from other data sets spanning older periods (prior 2011; e.g., Hussain et al., 2016). 


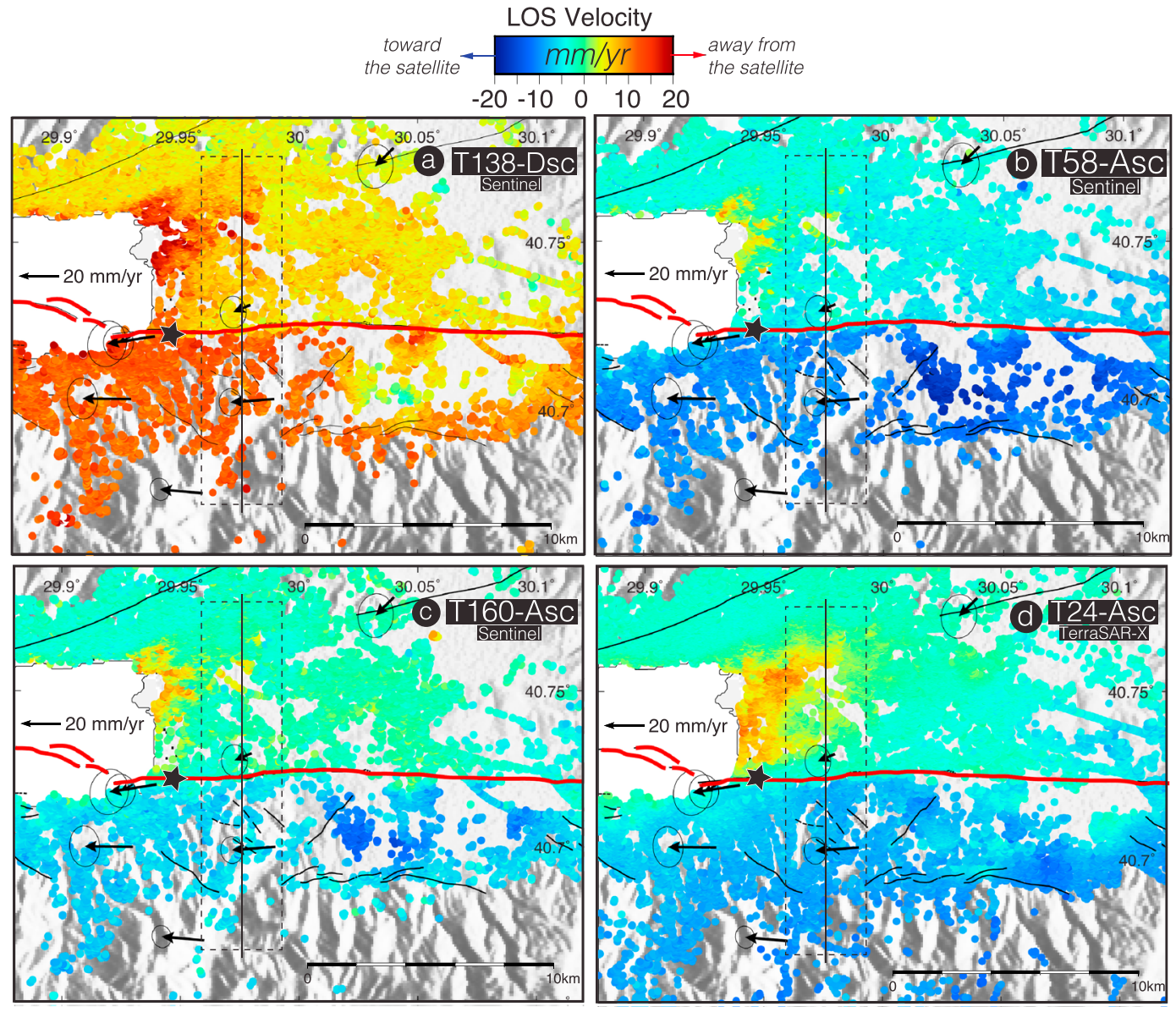

Figure 5. Close-up views on average velocity fields on four different tracks (same tracks as in Figure 4) along the Izmit Bay-Sapanca Lake segment of the Izmit earthquake rupture. The sharp velocity jump observed along the fault is attributed to shallow creep. Red lines indicate 1999 Izmit rupture (Barka et al., 2002), and black lines indicate active faults (Emre et al., 2013). Boxes with dashed lines contour data points selected to plot profile of Figure 6. Black star indicates location of the creep meter used in this study. Black vectors show post-2014, Global Positioning System horizontal velocities from Figure 2.

The velocity gradient across the fault is sharp and similar in shape in all fault-perpendicular line-of-sight velocity profiles from different, independent tracks and viewing geometries (Figure 6). The sign difference for ascending and descending tracks is as expected and related to the projection of the right-lateral motion on two opposite line of sights. The creep rate near the surface is proportional to the amount of the line-ofsight velocity offset across the fault measured on these fault-perpendicular profiles. The creep rates estimated for the three Sentinel tracks (T138, T58, and T160) that span the same time period and TerraSAR-X track (T24) are consistent with each other and are around $5 \mathrm{~mm} /$ year. In the next sections, we further explore the spatial variations of the creep rate along fault (sections 4.2 to 4.4) and its potential time evolution (section 4.5), through a time series analysis of surface deformation using all tracks.

\subsection{Fault-Parallel Horizontal Velocities Versus Vertical Velocities}

The InSAR technique measures projections of ground displacements only along the line-of-sight look angle. In order to retrieve the components of 3-D deformation, InSAR line-of-sight displacement fields observed under different viewing directions (i.e., different satellite tracks) over the same ground location must be combined (Wright et al., 2004).

In order to analyze the spatial variations of horizontal creep rate along the fault, we inverted the line-ofsight velocity fields to retrieve the horizontal (parallel to the east-west fault strike) and vertical 

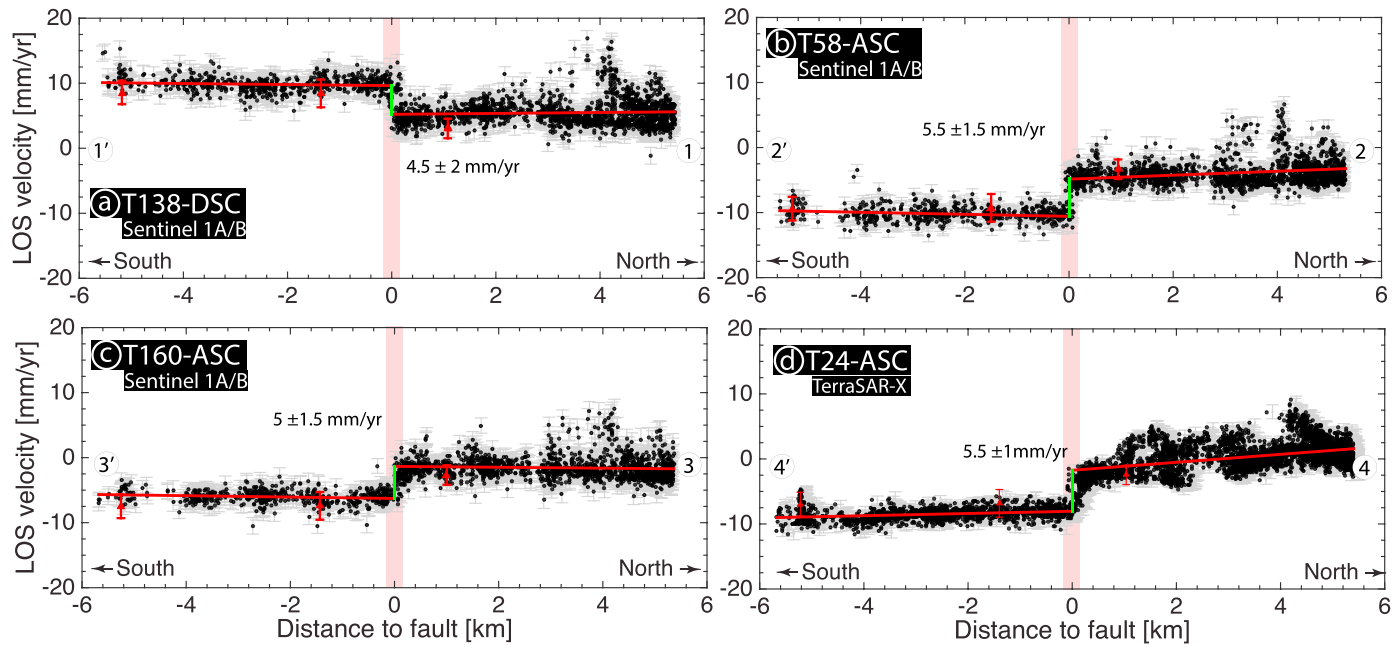

Figure 6. Line-of-sight (LOS) velocities from the four processed tracks along an unique north-south profile perpendicular to the 1999 fault rupture near Izmit (see dashed box in Figure 5 for the profile location). Black dots are permanent scatterer-interferometric synthetic aperture radar data points within the swath profile, projected onto its centerline. Gray error bars indicate $1 \sigma$ variations across profile. Transparent red box indicates location of fault where permanent scatterer points are not taken into account for calculation of best linear fit to the velocities (red lines). Jumps in the velocity profiles on the fault indicate surface creep rate (green lines). Red dots are post-2014 campaign Global Positioning System velocities projected onto LOS.

components using the formalism of Wright et al. (2004; Figures 7 and 8; see also Figures S5 for the associated uncertainties). We neglected here the motion along the north-south direction, a reasonable assumption for a strike-slip fault, consistent with observations of surface displacement during and after the 1999 earthquake. Only the line-of-sight mean velocity fields calculated from Sentinel 1 A/B images, which cover the same time interval, were used. Initially, we resampled the mean line-of-sight velocities for the ascending and descending tracks onto a similar grid (with a 200-m pixel spacing) using a nearest neighbor procedure. Subsequently, we selected pixels existing in all three velocity maps from ascending and descending tracks. Finally, the inversion was carried out for these pixels, taking into account the local incidence angle of the satellite view.

The discontinuity observed in line-of-sight velocity fields along the North Anatolian Fault is now much better pronounced in the east-west horizontal velocity field, especially along the Izmit section of the fault, between Izmit Bay and Sapanca Lake (Figures 7 and 8a). This sharp discontinuity disappears in the east of Sapanca Lake. We note a slight velocity gradient also along the Iznik fault $\sim 40 \mathrm{~km}$ south of the main North Anatolian Fault (Figure 7). The vertical component (Figure 8b) does not show any prominent discontinuity across the fault, which implies that aseismic slip is mostly purely horizontal. Variations in the vertical velocity field are seen at some places around the fault with various spatial patterns and rates, particularly in the Adapazari basin, as reported previously by Cakir et al. (2012) and Hussain et al. (2016) for the period between 2002 and 2010 (section 4.4).

\subsection{Horizontal Creep Rate Distribution Along Fault}

The E-W horizontal velocity field can be used to analyze the along strike variations of the creep. We first use a similar approach as Kaneko et al. (2013) to extract the surface creep rate. We plot a series of 8-km-long, 2-km-wide velocity profiles perpendicular to the fault, every $7 \mathrm{~km}$ along strike (Figure 8, showing one example of profile aa', and Figure 9). Velocities on both sides of the fault are fitted by a linear trend and the offset across fault between these best fit lines is measured, corresponding to the creep rate (Figure 9a). Figure 9c shows strong variations of this creep rate along fault. These variations are at first order consistent with the results from Hussain et al. (2016), with a maximum creep rate at the same location, south of Izmit, and an eastward decrease of the creep rate from the Izmit Bay to the east of Sapanca Lake. However, the maximum creep rate appears to have decreased from $\sim 10 \mathrm{~mm} /$ year during the 2002-2010 period covered by their Envisat data to $\sim 8 \mathrm{~mm} / \mathrm{year}$ for the 2014-2017 period covered 


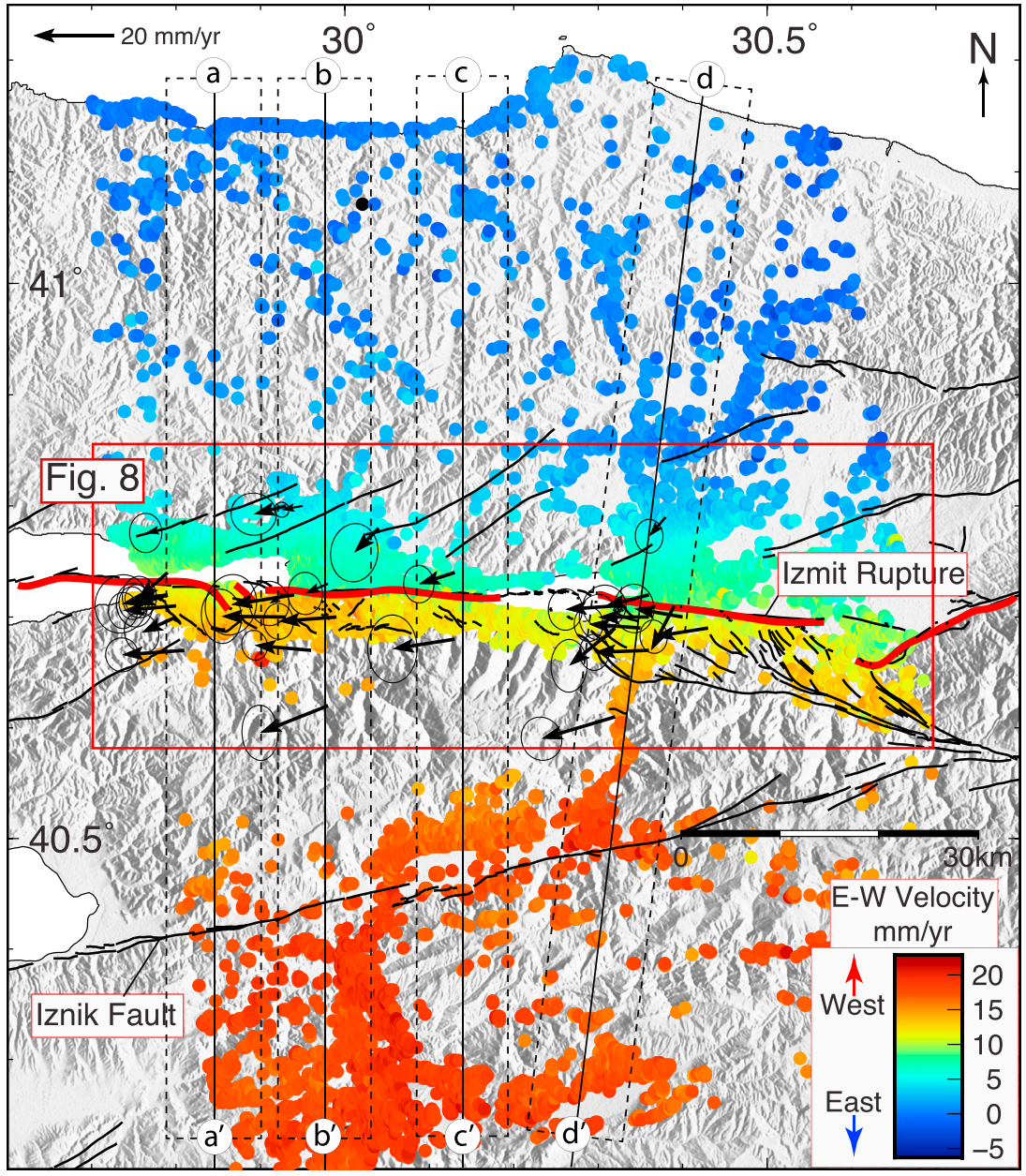

Figure 7. Fault-parallel, horizontal velocity field inverted from line-of-sight velocity fields of all sentinel satellite tracks used in this study (2014-2017). Black lines are mapped active faults in the region from Emre et al. (2013). Red lines indicate the 1999 Izmit rupture. Lines labeled A-A', B-B', C-C', and D-D' show locations of profiles of Figure 10. Black vectors show post-2014, Global Positioning System horizontal velocities from Figure 2.

by our Sentinel-1 data. This is expected due to the temporal decay of the creep rate since the Izmit earthquake (Cakir et al., 2012).

To further investigate the variations of the creep characteristics along fault (horizontal rate and depth), together with the tectonic loading (far-field loading rate and locking depth of the fault), we invert 80km-long fault-perpendicular horizontal velocity profiles (Figures 7 and 10), chosen to represent the along-strike variability of the creep seen in Figure 9. We use a Bayesian sampling algorithm, which allows uncertainties on model parameters and trade-offs between these parameters to be quantified (Figures 10 and 11). The shape of the velocity profiles (Figure 10) confirms the existence of two different deformation signals: (1) the long-wavelength arctangent shape associated with the interseismic tectonic strain accumulation and (2) a sharp step at the fault (visible only between the Izmit Bay and Sapanca Lake), due to surface creep. The interseismic slip rate $V$ is modeled using a screw dislocation at a depth $D_{1}$ in elastic half-space (Savage \& Burford, 1973). The creep, from surface to depth $D_{2}$, with a rate $C$, is modeled using the back-slip approach proposed by Savage (1983), as a combination of slip along the entire fault plane (product of $\mathrm{C}$ and Heaviside function, $\mathscr{H}(x)$ ), and a screw dislocation at depth $D_{2}$ in reverse sense to the plate motion. In this configuration, creep occurs from the surface down to a shallow depth $D_{2}$ only and the fault is fully locked between depths $D_{1}$ and $D_{2}$. The total horizontal slip rate $v(x)$ derived from InSAR can thus be expressed as 

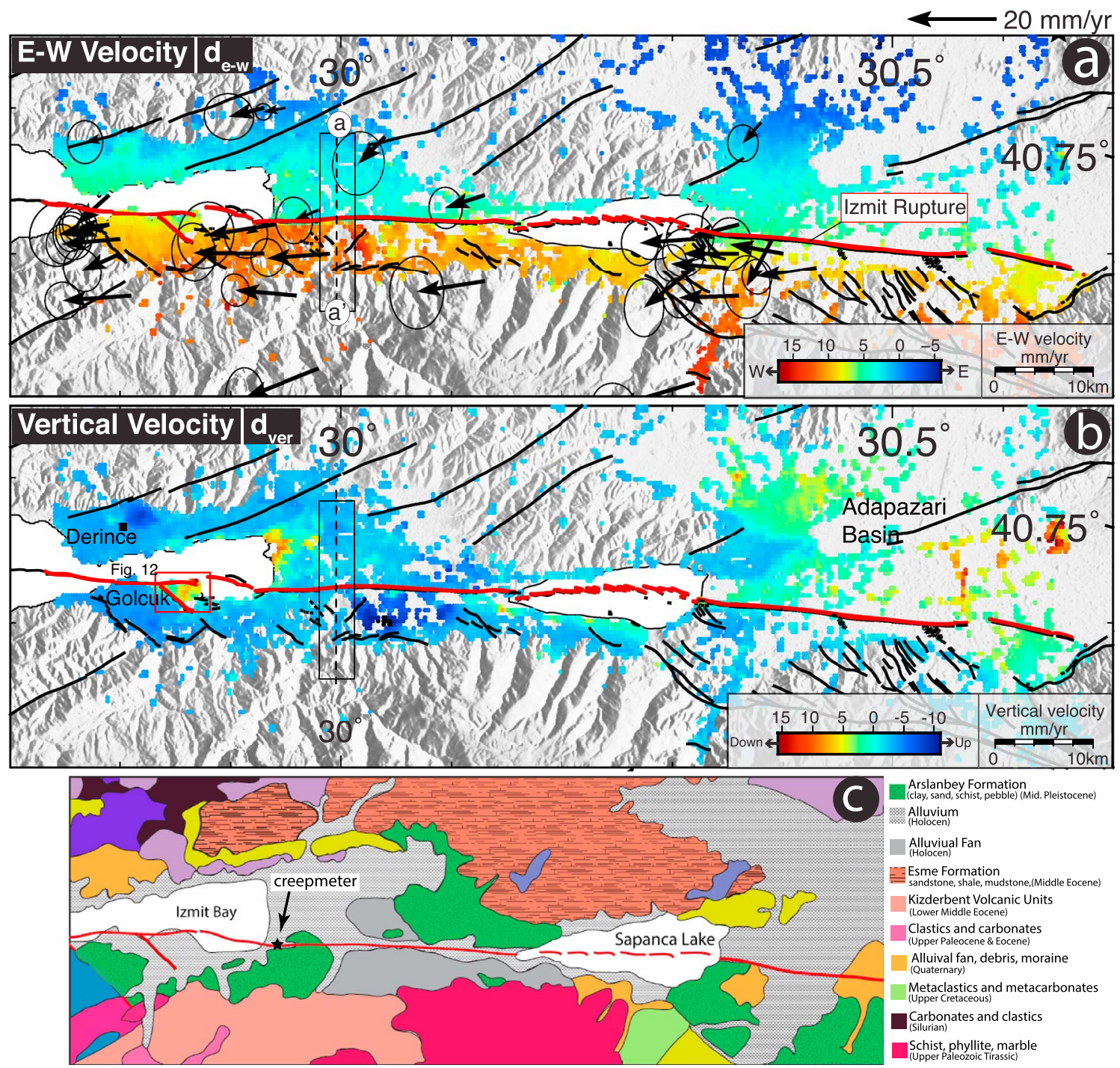

Figure 8. Enlarged view of the Izmit creeping section of the North Anatolian Fault. Fault-parallel, horizontal (a) and vertical (b) velocity fields inverted from lineof-sight velocity fields of Sentinel satellite tracks used in this study (2014-2017). A sharp discontinuity observed along the 1999 Izmit rupture reveals shallow creep between the Sapanca Lake to the east and the Gulf of Izmit to the west. The black rectangle with dashed line labeled a-a' in east-west velocity field indicates the location of the profile shown in Figure 9a. It is superimposed as well on vertical velocity field in (b) in order to highlight the continuity of the vertical velocity across fault. The red box indicates location of maps shown in Figure 12. Black vectors show post-2014, Global Positioning System horizontal velocities from Figure 2. (c) Geological map of the study region simplified from MTA-Turkey General Directorate of Mineral Research and Exploitation 1/500,000 scale geologic map.

$$
v(x)=-\frac{V}{\pi} \arctan \left(\frac{x}{D_{1}}\right)+\mathrm{C}\left[\frac{1}{\pi} \arctan \left(\frac{x}{\mathrm{D}_{2}}\right)-\mathscr{H}(x)\right]+a,
$$

where $x$ is the distance $(\mathrm{km})$ along a direction perpendicular to the fault and $a$ is a constant velocity of adjustment between measured velocities and model.

We use the Bayesian algorithm of Goodman and Weare (2010) with a Markov Chain Monte Carlo sampler (Foreman-Mackey et al., 2013) to explore the model parameter space $\left(V, D_{1}, C, D_{2}\right.$, and $\left.a\right)$ and their full uncertainties. We use Gaussian prior distributions on the locking depth, centered on $D_{1}=12 \mathrm{~km}$ (depth of seismogenic zone) with a $1 \sigma$ value of $5 \mathrm{~km}$ (Ozalaybey et al., 2002), and on the tectonic slip rate, centered on $V=25 \mathrm{~mm} /$ year (e.g., Cakir et al. (2012), Ergintav et al. (2014)) with a $1 \sigma$ value of $7 \mathrm{~mm} /$ year. An important additional constraint we impose here is that the maximum depth of the fault creep must be less than the locking depth, that is, $D_{2} \leq D_{1}$ as in Hussain et al. (2016). We assume a uniform prior probability distribution 

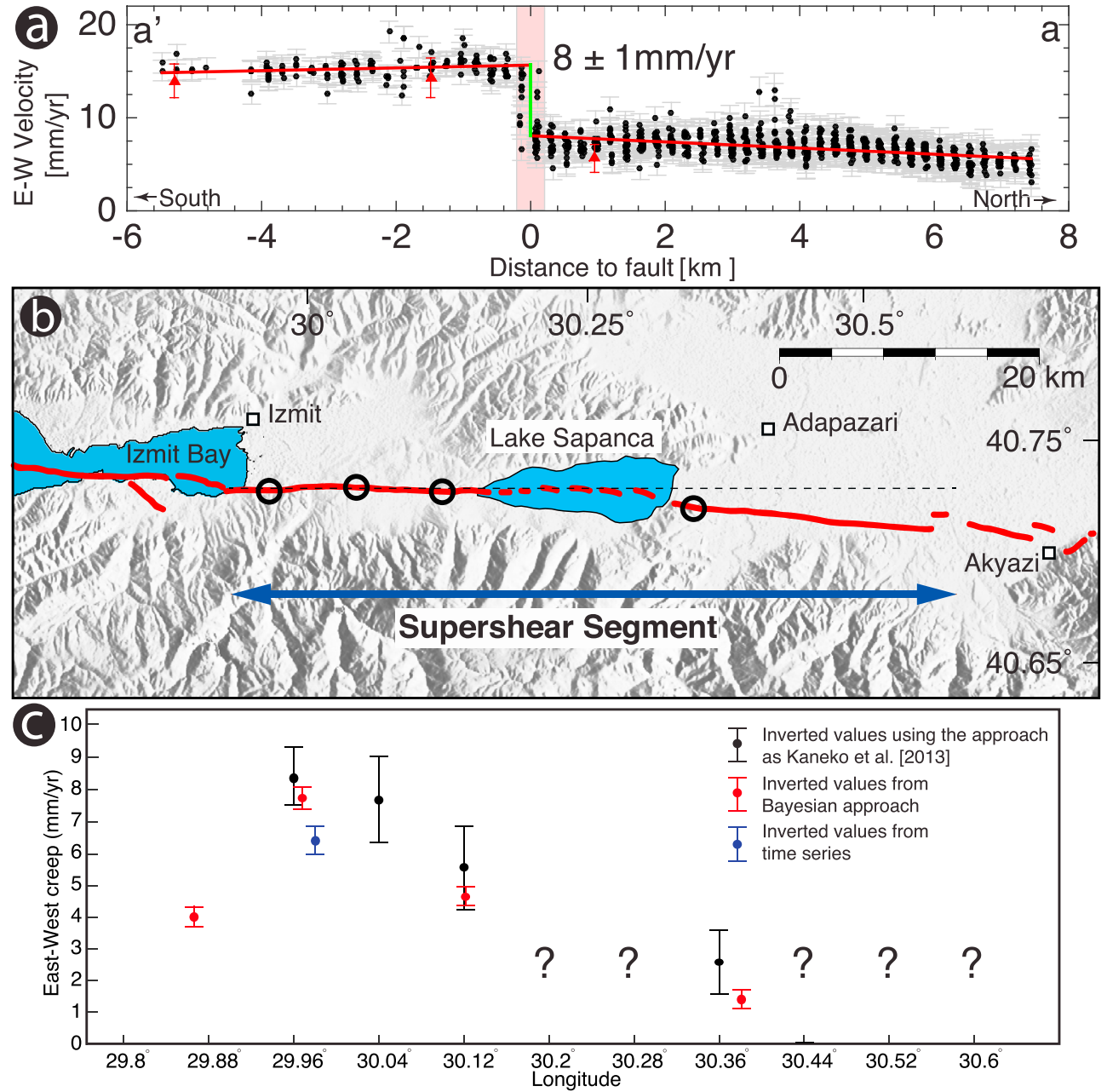

Figure 9. (a) Measuring horizontal creep rate along a fault-perpendicular velocity profile (profile a-a' in Figure 8). Black dots are E-W permanent scatterers velocities within the box projected onto profile centerline, with $1 \sigma$ uncertainties shown by gray error bars (from data inversion, see text for details). Red straight lines correspond to best fit to the data on both sides of the fault (with data within a 200-m distance to the fault, marked with transparent red box are ignored). The creep rate is the vertical distance (green line) between the two red lines on the profile. (b) Map of the 1999 Izmit rupture with (c) variations of horizontal creep rate along fault, estimated as in (a), inverted using a Bayesian approach or inverted from time series analysis (black, red, blue dots and error bars, respectively). Positive creep values in east-west direction indicate right-lateral motion.

for $C, D_{2}$, and $a$ within the bounds $0<C<8 \mathrm{~mm} /$ year, $0<D_{2}<20 \mathrm{~km}$, and $-20<a<20 \mathrm{~mm} /$ year. For each model parameters or combination of parameters, we obtain posteriori probability density functions to analyze uncertainties and covariances and choose the mean of posteriori solution as the most representative one, close to the maximum solution as posteriori probability density functions are mostly Gaussian (Figure 11).

The results of the parameters inversion are shown in Figure 10. Figure 11 shows a posteriori probability density functions for estimated parameters on profile $b-b^{\prime}$ as an example (with high mean values and low two-sigma values), as for all profiles (see supporting information for profiles a-a', c-c', and d-d'). The most prominent velocity step, that is, the maximum creep rate $(7 \pm 0.5 \mathrm{~mm} /$ year $)$ is observed on this profile $b^{-} b^{\prime}$ and is consistent, within error bars, with the velocity surface offset measured directly from a short-length profile (Figure 9c). Consistently, as well, profile c-c' show a creep rate lower than for profile b-b'. No significant horizontal creep is required by the models for the profile $\mathrm{d}-\mathrm{d}^{\prime}$. This confirms that different segments of the Izmit rupture have presently different slip behaviors. Trade-offs exist between some parameters, as expected, especially between the rates and the depths, while the creep velocity and the tectonic loading 

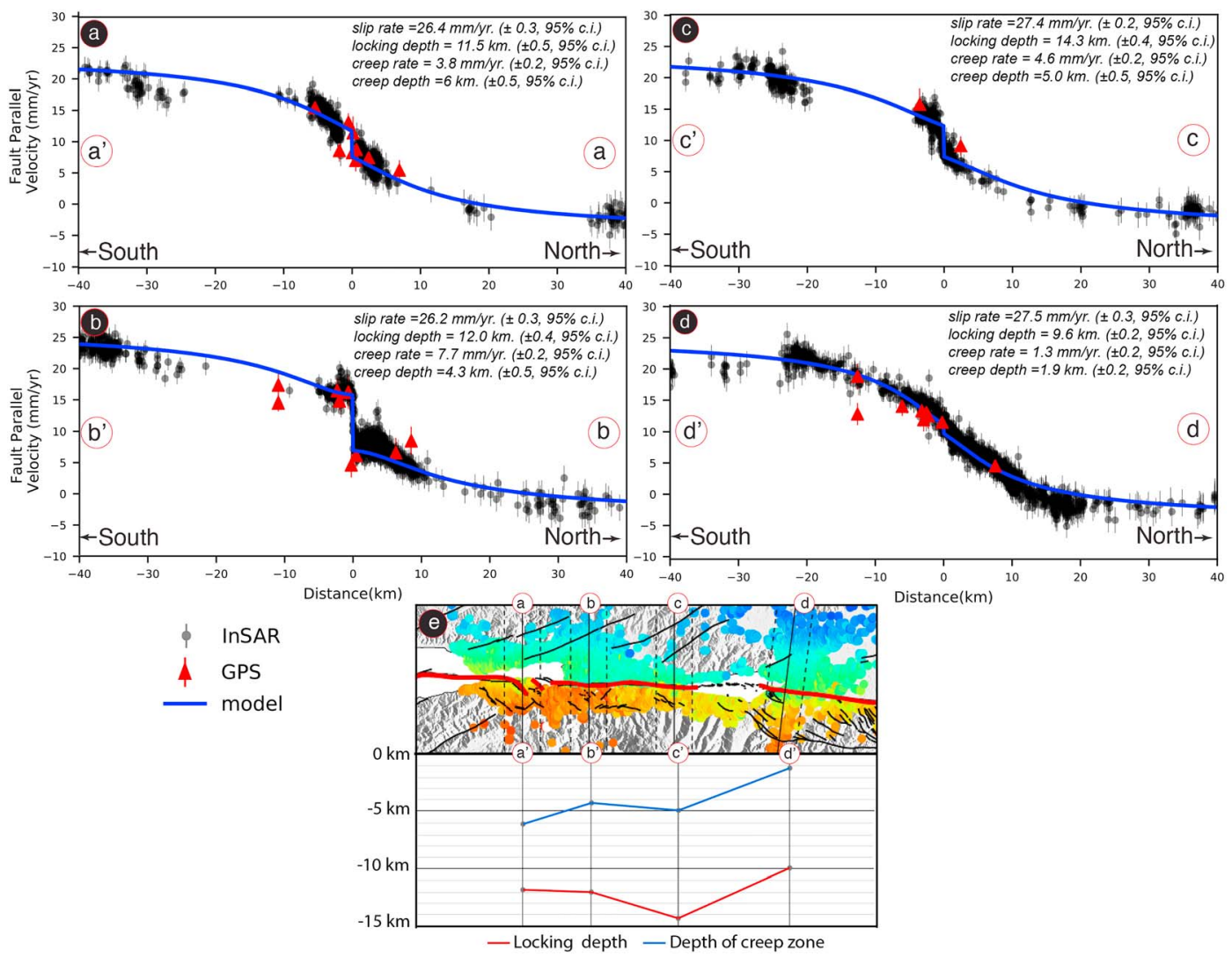

Figure 10. Observed and modeled horizontal velocity profiles (a-d). Profiles are perpendicular to the fault and are shown on Figure 7. Blue curves show the mean solution of the interseismic model with shallow creep, from the Bayesian inversion, with corresponding parameters and one-sigma value given above each curve. Black arrows point to the location of the mapped active fault. (e) Map view of profiles in a-d in the near field with spatial variations of locking depth and creep depth estimated for each profile. InSAR = interferometric synthetic aperture radar; GPS = Global Positioning System.

rate appear uncorrelated (Figure 11). Mean solutions for the creeping depth vary around the value of $5.5 \mathrm{~km}$ (Figure 10e), consistent with previous studies (Cakir et al., 2012; Hussain et al., 2016) for the central segment of the rupture.

\subsection{Vertical Motion Along the 1999 Rupture}

The vertical velocity field shows various anomalies along and near the Izmit rupture zone (Figure $8 \mathrm{~b}$ ). While local subsidence and uplift areas with varying spatial extent and rate are observed in the vicinity of the fault, vertical motion localized on the fault zone is observed only in the Golcuk pull apart basin bounded to the south by an oblique normal fault, on which $2.5 \mathrm{~m}$ of vertical offset was observed during the 1999 Izmit earthquake (Barka et al., 2002). The subsidence with a rate of the order of $10 \mathrm{~mm} /$ year in Gölcük is bounded by this normal fault. Figure 12 shows the highest spatial resolution of the line-of-sight velocity across the fault from the TerraSAR-X data set, highlighting a high gradient at the fault location. Such a sharp gradient across fault may be indicative of creep at shallow depth. However, without any complementary data or modeling (out of scope of this paper), we cannot exclude that the subsidence is related to compaction of unconsolidated sediments in the basin or water pumping.

Another distinctive feature in the vertical velocity field for the studied period 2011-2017 is the pattern of localized subsidence in the city of Izmit. This subsidence was first reported by Cakir et al. (2012) using InSAR analysis of Envisat images between 2003 and 2009. It likely results from urbanization along the northeastern boundary of the Izmit basin. As reported by Hussain et al. (2016) using Envisat ASAR images acquired between 2002 and 2012, the Adapazari basin, a deep sedimentary basin, is subsiding at a rate of $\sim 6 \mathrm{~mm} /$ year. The most devastating effects of liquefaction were observed in this basin during the 17 


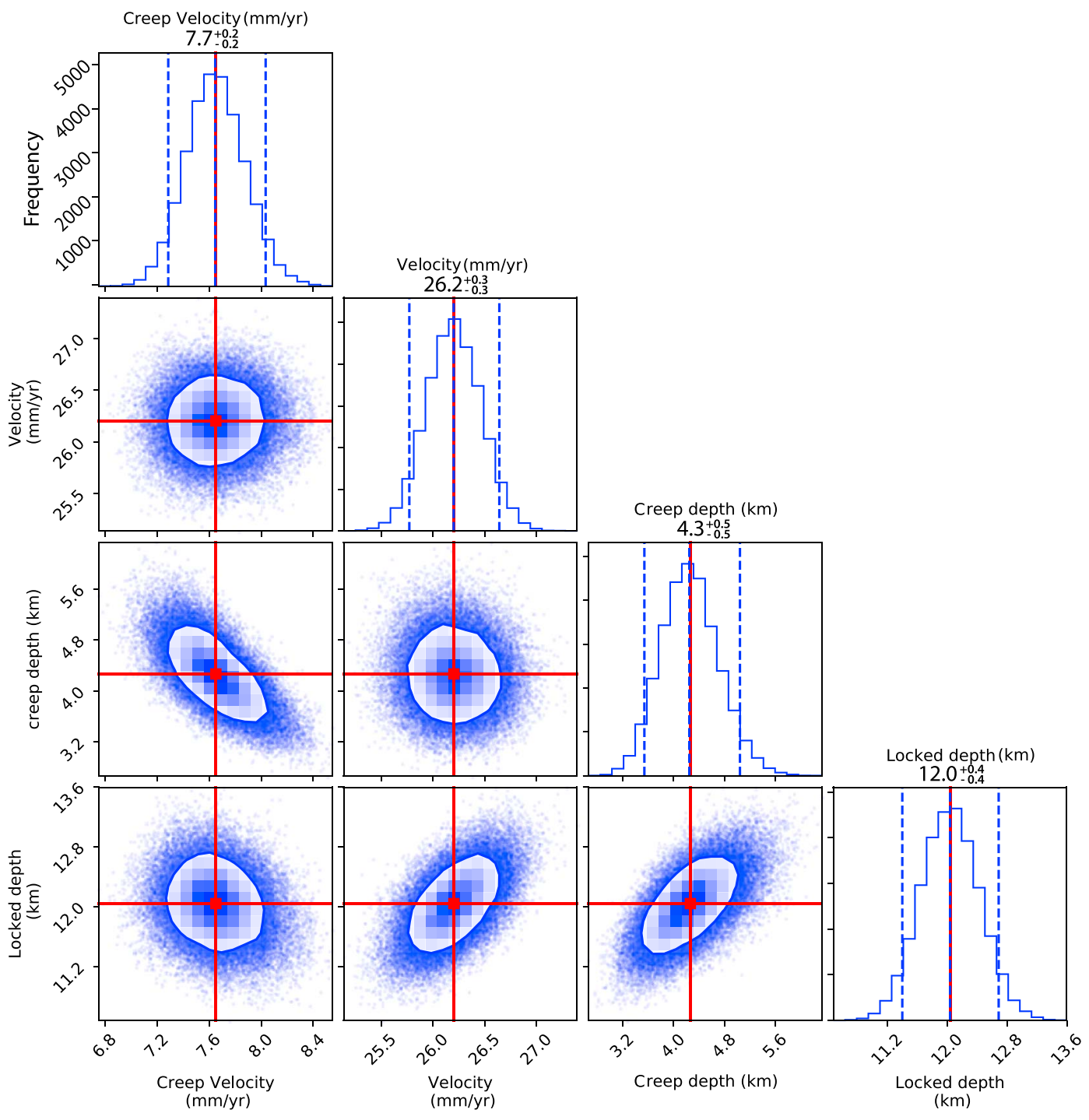

Figure 11. One-dimensional and two-dimensional sampled probability distributions obtained from Monte Carlo Markov Chain exploration of the model parameters assuming a priori uniform distribution for all model parameters but locking depth $D_{1}$ (Gaussian distribution), for profile $\mathrm{b}-\mathrm{b}^{\prime}$. The diagonal plots display the one-dimensional marginal distribution for each parameter independently in the histograms. The panels with clouds of points display the marginal twodimensional distributions. The red solid lines indicate the mean value for each model parameter. Blue dashed lines mark the $95 \%$ confidence interval of the probability density functions. The values above each histogram indicate the mean value.

August 1999 Izmit earthquake (Bol et al., 2010). A clear velocity gradient is observed west of the Adapazari, most likely marking a passive boundary between competent bedrock in the north on Sapanca Lake and Holocene loose fluvial, palustrine and lacustrine deposits in the Adapazari depression (no active fault is known at this boundary). Finally, an area of uplift, with an uplift rate of $\sim 6 \mathrm{~mm} /$ year, is observed in the Derince neighborhood in the province of Kocaeli northwest of the Izmit bay (Figure $8 b$ ), as reported previously by Cakir et al. (2012).

\subsection{Temporal Evolution of Creep}

In order to identify potential temporal variations of the creep rate, we performed a time series analysis of the surface displacement using all Sentinel 1A/B data. For each Sentinel track independently, we computed the temporal evolution of the fault-perpendicular line-of-sight displacement profile shown on Figure 5 and at each time step of the time series, we computed the line-of-sight displacement offset at the fault (corresponding to surface creep projected in line of sight), using the Kaneko et al. (2013) approach as above in section 4.3. 


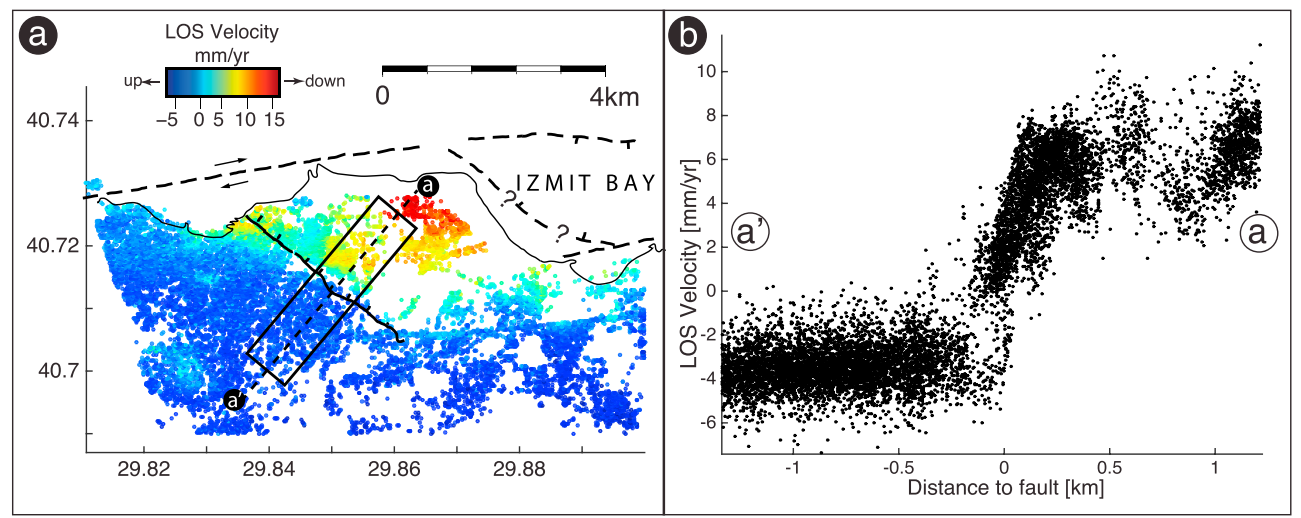

Figure 12. (a) Close-up view of line-of-sight (LOS) velocities across the Golcuk normal fault calculated from TerraSAR-X ascending track 24 for the period of 2011-2015. Fault location is indicated by black solid line inland and dashed lines offshore, inferred from fault geometry inland and bathymetry and shallow seismic profiles in the Sea of Marmara (Barka et al., 2002). (b). LOS velocity profile along profile a-a' shown in (a).

These displacement offsets were then converted into horizontal creep, assuming pure horizontal motion, as justified by the results shown in Figure 8, and no motion along the north-south direction (i.e., pure faultparallel horizontal motion).

Figure 13 shows the derived temporal evolutions of this surface creep for all three independent Sentinel tracks, and the creep rates appear remarkably consistent. The mean creep rate is $6.5 \pm 0.5 \mathrm{~mm} /$ year, which is in a good agreement with the average creep rate of $\sim 7 \pm 0.5 \mathrm{~mm} /$ year estimated from the analyses presented Figures 9 and 10. In order to minimize noise and explore creep rate variations, the obtained displacements (green, orange, and magenta points on Figure 13a) were averaged using 2-month bins (blue dots on Figure 13a show the average value with the corresponding one standard deviation within the bin). This reveals a transient creep event in the time series around December 2016 that lasted for less than 1 month. A linear inversion of the creep rate, done separately for the periods before and after this month, allows estimating (1) an amplitude of $\sim 10 \mathrm{~mm}$ for this transient creep event, which is equivalent to 1.5 years of steady creep at the mean rate of $\sim 7 \mathrm{~mm} /$ year, and (2) its approximate duration of 3 weeks.

To test the statistical validity of this creep event detection from noisy InSAR time series, we computed the Akaike Information Criterion (AIC, Akaike, 1974), as currently done for the analysis of GPS time series (e.g., Nishimura et al., 2013). The AIC is computed first for each time series independently, for a model of linear velocity and a model with a transient in addition. The AIC difference between the two models $(\triangle \mathrm{AIC}$ ) is indicative of the most robust model (Figure $13 \mathrm{c}$, with a positive difference $\Delta \mathrm{AIC}$ when the transient model is favored). We then sum up the $\Delta \mathrm{AIC}$ of the three independent time series (Figure 13d). The 1-month transient creep event of December 2016 discussed above has the highest $\Delta$ AIC for all three tracks, thus for the summed $\triangle \mathrm{AIC}$. Two other minor peaks of $\Delta \mathrm{AIC}$ may also correspond to other transients during the earlier period, only sampled every 12 days.

We also compared the temporal trend of the InSAR time series with that of a creep meter installed near the epicenter of the Izmit earthquake (see location on Figure 2). This creep meter recorded two transient creep events in September 2015, with $\sim 2.5 \mathrm{~mm}$ of slip, and in December 2016, with $\sim 1 \mathrm{~mm}$ of slip (Figure 13a). We note the temporal correlation with two of the transients detected by InSAR, although slip amplitudes measured by the creep meter are up to 10 times smaller than the slip amount $(10 \mathrm{~mm})$ estimated using InSAR time series. Such slip discrepancy is likely suggesting that the creep meter underestimates the creep as it encompasses a small fraction (about $10 \mathrm{~m}$ ) of the fault zone.

\section{Discussion}

Our results derived from a PS-InSAR analysis using high-resolution multisensor SAR images and GPS campaign measurements along the 1999 Izmit rupture reveal that the fault section with supershear velocities during the earthquake, between the Izmit Bay and Sapanca Lake (Bouchon et al., 2001), is still creeping 

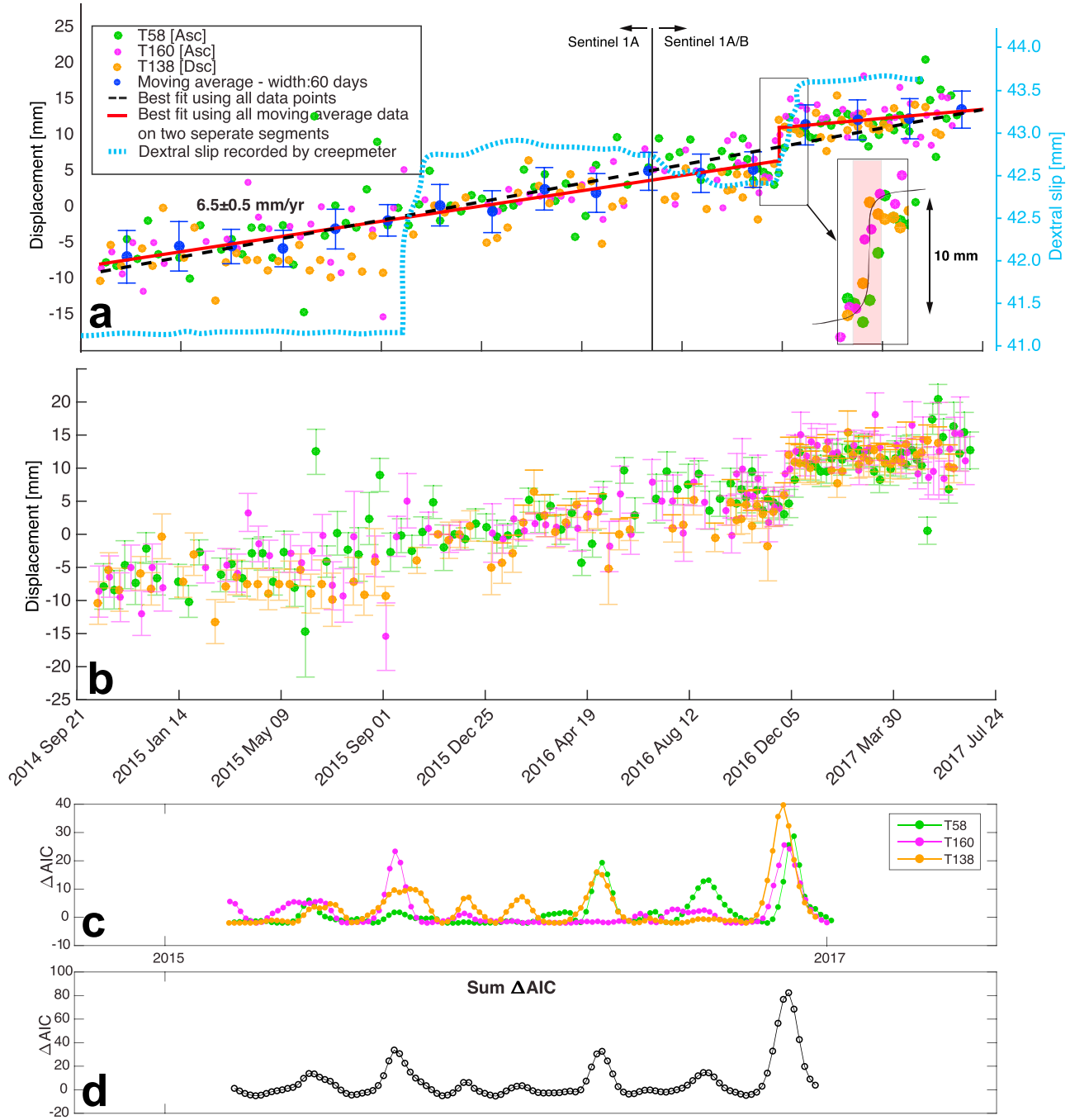

Figure 13. Time series of horizontal creep estimated along a fault-perpendicular profile (see location of the profile in Figure 5) using all Sentinel data sets and assuming pure horizontal motion parallel to the fault. (a) Blue dots are the binned averages every 60 days. Error bars show one standard deviation of the distribution of the points within each bin. A clear transient event is seen around December 2016 (see inset). Red lines are fitted to the two separate segments of the bin-averaged data before and after this month. The vertical red line shows the transient creep event amplitude calculated from the offset of the two red lines. Black dashed line is the best fitting line for the entire data set points that represent the mean rate ( $\sim 6.5 \mathrm{~mm} /$ year). The period of transient creep, from mid-November to mid-December 2016, is highlighted by the transparent red background in the inset. Blue dashed line shows surface slip measured by the creep meter for comparison. (b) Raw data showing estimated creep displacement with error bars that indicate two-sigma standard deviation of the measurements. (c) Difference of AIC (Akaike Information Criterion) between linear creep rate models with and without a transient, computed for each track independently. $\triangle \mathrm{AIC}$ is positive when the transient model is preferred. (d) Summation of all three $\triangle$ AIC, highlighting one major creep burst.

19 years after the earthquake. The average creep rate during the 2014-2017 Sentinel-1 period reaches up to $\sim 8 \mathrm{~mm}$ /year south of Izmit, a maximum value about half than that reported after the Izmit earthquake and during the 2002-2010 Envisat period (Cakir et al., 2012; Hussain et al., 2016). We discuss below the potential factors controlling this long-lasting creep and its along-strike variations, as well as the mechanical implications of the 1-month creep burst detected during the 3-year period covered by Sentinel-1 data.

\subsection{Spatial Distribution of Creep and Geometrical and Lithological Control}

Supershear velocity ruptures, as the 1999 Izmit earthquake, have mostly been observed along major strikeslip faults with overall simple planar geometries (e.g., Bouchon et al., 2010; Michel \& Avouac, 2002), but with local geometrical complexities, stress, or/and frictional heterogeneities along faults that can favor the 
transition to supershear velocities (Liu \& Lapusta, 2008). The spatial coincidence between the presently creeping and the 1999 supershear velocity segments of the North Anatolian Fault may suggest similar controlling factors for these two phenomena. A possible influence of fault geometry at all scales on creep has previously been suggested (Jolivet, Candela, et al., 2015). The very linear geometry of the Izmit-Sapanca Lake and Sapanca Lake-Akyazi segments may promote creep, with fault steps and jogs at these segments extremities controlling the creep lateral extent and first-order segmentation (Figure 9).

Several mechanisms of creep have been proposed that also correlate the existence of creep with the nature of the rocks in the fault zone (Moore \& Lockner, 2013; Moore \& Rymer, 2007). Along the Ismetpasa creeping section of the North Anatolian Fault, Kaduri et al. $(2017,2018)$ showed the important role of lithology and mineral transformation in the fault zone on frictional properties along fault, therefore on creep distribution along fault. The clay gouges associated with the aseismic slip on this fault section (Figure 8c) are rich in weak minerals, such as saponite and other smectites (Kaduri et al., 2017). These low friction minerals have been observed as well along the creeping segments of the San Andreas Fault in California, and the Long Valley Fault in Taiwan (Moore \& Rymer, 2007; Thomas et al., 2014). Along the Izmit creeping section, similar detailed analysis of rocks compositions in the fault zone remain to be done. However, geological maps reveal that the central section of the 1999 Izmit rupture coinciding with the maximum surface creep puts in contact Quaternary alluvial deposits in the central depression of the Izmit basin, north of the fault, and Eocene volcanic units south of the fault (Figure 8c). The weathering of these lenses of volcanic rocks could produce weak minerals such as saponite, favoring the persistency of high creep rate in this location (Kaduri et al., 2017). These volcanic units become thinner to the east of Sapanca Lake, which could explain why creep is vanishing eastward.

\subsection{High Temporal Resolution InSAR Data Reveal Burst-Like Behavior of Creep}

The high temporal resolution provided by the Sentinel-1 data set reveals the existence of at least one burst of creep at the end of 2016, with a good temporal correlation with a transient slip event detected by a creep meter located nearby. Such type of transient creep event had previously been reported along the Ismetpasa creeping section to the east, based on the analysis of short repeat time SAR acquisitions from the COSMO-SkyMed constellation, over a limited 1-year period (Rousset et al., 2016). The maximum amplitude ( $\sim 10 \mathrm{~mm}$ in our case, whereas it was $\sim 20 \mathrm{~mm}$ along the Ismetpasa section) and duration of these shallow bursts ( $\sim 1$ month) are similar. The growing number of evidence for such creep bursts along the North Anatolian Fault, as also suggested by long time series of creepmeter measurements (Altay \& Sav, 1991; Bilham et al., 2016), and along other major strike-slip faults worldwide (De Michele et al., 2011; Jolivet, Simons, et al., 2015; Khoshmanesh \& Shirzaei, 2018; Pousse-Beltram et al., 2016), suggest that continuously decaying afterslip or steady interseismic creep may not be the rule for creep behavior. New mechanical models are required to account for coupling temporal variations at shallow depth and recurrent creep bursts triggering. Long and temporally dense sets of InSAR data will be a key to constrain these models and further investigate the magnitude, depth, return period, and dynamics of such transient creep episodes, as well as their contribution to tectonic strain release.

\section{Conclusion}

We have studied the spatiotemporal evolution of surface displacements along the central section of the 1999 Izmit earthquake with an unprecedented temporal resolution, using 307 SAR images acquired between 2011 and 2017, combined with GPS campaign measurements acquired every 6 months from 2014 to 2016. The joint analysis of GPS data and all SAR images acquired from multiviewing geometries and multisensors, through a PS-InSAR data analysis, allowed to extract both horizontal and vertical motion along the fault and relevant slip parameters on fault.

Subsidence in the Adapazari basin is still observed, at a rate of $\sim 6 \mathrm{~mm} /$ year, as previously reported by Hussain et al. (2016) using Envisat ASAR images. Other localized subsidence and uplift areas are identified around the Izmit Bay area. A prominent subsidence is observed for the first time on the hanging wall of the Golcuk normal fault, which marks the southwestern boundary of a releasing stepover along the North Anatolian Fault, ruptured during the Izmit earthquake. The high velocity gradient of $\sim 10 \mathrm{~mm} /$ year detected across this oblique normal fault could be due either to passive subsidence in the basin located northeast of it or most likely to shallow afterslip. 
Our results also show that creep along the Izmit section, previously interpreted as afterslip following the 1999 earthquake, is still taking place and continues to decay more than 19 years after the earthquake. The along-strike distribution of the average creep rate is consistent with previous GPS and InSAR studies (Cakir et al., 2012; Hussain et al., 2016), with a maximum creep rate now reduced to $\sim 8 \mathrm{~mm} /$ year. Creep is spatially correlated with the presence of volcanic rocks on the southern side of the North Anatolian fault that could produce weak minerals at the origin of creep. The analysis of the high temporal resolution of Sentinel-1 data reveals the existence of temporal fluctuations of the creep rate with the detection of a onemonth burst of creep in December 2016, with an amplitude of $\sim 10 \mathrm{~mm}$. The occurrence of this transient event, together with similar observations along the Ismetpasa creeping section of the North Anatolian Fault, suggests that fault afterslip is not evolving continuously with time but can occur through a combination of continuous creep that decays with time after a major earthquake and accelerating bursts of creep events.

\section{Acknowledgments}

SAR (TerraSAR-X) data sets were obtained through the GSNL Marmara Region Permanent Supersite (available at http://geo-gsnl.org/supersites/ permanent-supersites/marmararegion-supersite/). Processing of Sentinel $1 \mathrm{~A} / \mathrm{B}$ images is performed at TUBITAK ULAKBIM, High Performance and Grid Computing Center (TRUBA resources). This study received funding from the Norwegian Research Council, project HADES, grant 250661 to F. R., TUBITAK project $113 Y 102$ to Z. C., and Bogaziçi University Research Fund Grant 12200 to S. E. This is part of the PhD dissertation of Gokhan Aslan who is supported by the French Embassy in Turkey (Bourse Etudes scholarship program 889075 G), University Grenoble Alpes IDEX project scholarship, Université Grenoble Alpes LabeX OSUG@2020 project to C. L., and CMIRA scholarship program provided by the Rhone-Alpes Region. The creep meters were supported by NSF EAR 1622720. We thank B. Rousset for discussions and help in the conception of Figure. We also thank the editor P. Tregoning and two anonymous reviewers for the constructive comments.

\section{References}

Akaike, H. (1974). A new look at the statistical model identification. IEEE Transactions on Automatic Control, 19(6), 716-723. https://doi. org/10.1109/TAC.1974.1100705

Altay, C., \& Sav, H. (1991). Continuous creep measurement along the north Anatolian Fault zone. Bulletin of Geological Congress, Turkey, 6, 77-84.

Ambraseys, N. (1970). Some characteristic features of the Anatolian fault zone. Tectonophysics, 9(2-3), 143-165. https://doi.org/10.1016/ 0040-1951(70)90014-4

Armijo, R., Pondard, N., Meyer, B., Uçarkus, G., de Lépinay, B., Malavieille, J., et al. (2005). Submarine fault scarps in the Sea of Marmara pull-apart (North Anatolian Fault): Implications for seismic hazard in Istanbul. Geochemistry, Geophysics, Geosystems, 6, Q06009. https://doi.org/10.1029/2004GC000896

Avouac, J.-P. (2015). From geodetic imaging of seismic and aseismic fault slip to dynamic modeling of the seismic cycle. Annual Review of Earth and Planetary Sciences, 43(1), 233-271. https://doi.org/10.1146/annurev-earth-060614-105302

Aytun, A. (1982). Creep measurements in the Ismetpasa region of the North Anatolian fault zone. In A. M. Isikara \& A. Vogel (Eds.), Multidisciplinary approach to earthquake prediction (pp. 279-292). Braunshweig/Wiesbaden: Friedr. Vieweg and Sohn. https://doi.org/ 10.1007/978-3-663-14015-3_20

Barka, A., Akyuz, H. S., Sunal, G., Cakir, Z., Dikbas, A., Yerli, B., et al. (2002). The surface rupture and slip distribution of the 17 August 1999 Izmit earthquake (M 7.4), North Anatolian Fault. Bulletin of the Seismological Society of America, 92(1), 43-60. https://doi.org/ $10.1785 / 0120000841$

Barnhart, W. D. (2017). Fault creep rates of the Chaman fault (Afghanistan and Pakistan) inferred from InSAR. Journal of Geophysical Research: Solid Earth, 122, 372-386. https://doi.org/10.1002/2016JB013656

Bekaert, D. P. S., Walters, R. J., Wright, T. J., Hooper, A. J., \& Parker, D. J. (2015). Statistical comparison of InSAR tropospheric correction techniques. Remote Sensing of Environment, 170, 40-47. https://doi.org/10.1016/j.rse.2015.08.035

Bilham, R. (1989). Surface slip subsequent to the 24 November 1987 Superstition Hills, California, earthquake monitored by digital creepmeters. Bulletin of the Seismological Society of America, 79, 424-450.

Bilham, R., Ozener, H., Mencin, D., Dogru, A., Ergintav, S., Cakir, Z., et al. (2016). Surface creep on the North Anatolian Fault at Ismetpasa, Turkey, 1944-2016. Journal of Geophysical Research: Solid Earth, 121, 7409-7431. https://doi.org/10.1002/2016JB013394

Bol, E., Arel, E., Önalp, A., Sert, S., \& Ozocak, A. (2010). Liquefaction of silts: The Adapazari criteria. Bulletin of Earthquake Engineering, 8(4), 859-873. https://doi.org/10.1007/s10518-010-9174-X

Bouchon, M., Bouin, M. P., Karabulut, H., Toksoz, M. N., Dietrich, M., \& Rosakis, A. J. (2001). How fast is rupture during an earthquake? New insights from the 1999 Turkey earthquakes. Geophysical Research Letters, 28(14), 2723-2726. https://doi.org/10.1029/ 2001GL013112

Bouchon, M., Karabulut, H., Bouin, M.-P., Schmittbuhl, J., Vallée, M., Archuleta, R., et al. (2010). Faulting characteristics of supershear earthquakes. Tectonophysics, 493(3-4), 244-253. https://doi.org/10.1016/j.tecto.2010.06.011

Burford, R. O., \& Harsh, P. W. (1980). Slip on the San Andreas Fault in central California from alignment array surveys. Bulletin of the Seismological Society of America, 70, 1223-1261.

Bürgmann, R. (2018). The geophysics, geology and mechanics of slow fault slip. Earth and Planetary Science Letters, 495, 112-134. https:// doi.org/10.1016/j.epsl.2018.04.062

Bürgmann, R., Ergintav, S., Segall, P., Hearn, E. H., McClusky, S., Reilinger, R. E., et al. (2002). Time-dependent distributed Afterslip on and deep below the Izmit earthquake rupture. Bulletin of the Seismological Society of America, 92(1), 126-137. https://doi.org/10.1785/ 0120000833

Bürgmann, R., Schmidt, D., Nadeau, R., d'Alessio, M., Fielding, E., Manaker, D., et al. (2000). Earthquake potential along the northern Hayward fault. Science, 289(5482), 1178-1182. https://doi.org/10.1126/science.289.5482.1178

Bürgmann, R., \& Thatcher, W. (2013). Space geodesy: A revolution in crustal deformation measurements of tectonic processes. In M. E. Bickford (Ed.), In The web of geological sciences: Advances, impacts and interactionsGSA spec. Pap. (Vol. 500, pp. 397-430). Boulder, CO: GSA.

Cakir, Z., Akoglu, A. M., Belabbes, S., Ergintav, S., \& Meghraoui, M. (2005). Creeping along the Ismetpasa section of the North Anatolian Fault (Western Turkey): Rate and extent from InSAR. Earth and Planetary Science Letters, 238(1-2), 225-234. https://doi.org/10.1016/j. epsl.2005.06.044

Cakir, Z., Barka, A., de Chabalier, J.-B., Armijo, R., \& Meyer, B. (2003). Kinematics of the November 12, 1999 (Mw = 7.2) Düzce earthquake deduced from SAR interferometry. Turkish Journal of Earth Sciences, 12, 105-118.

Cakir, Z., de Chabalier, J. B., Armijo, R., Meyer, B., Barka, A., \& Peltzer, G. (2003). Coseismic and early postseismic slip associated with the 1999 Izmit earthquake (Turkey), from SAR interferometry and tectonic field observations. Geophysical Journal International, 155(1), 93-110. https://doi.org/10.1046/j.1365-246X.2003.02001.x 
Cakir, Z., Ergintav, S., Ozener, H., Dogan, U., Akoglu, A. M., Meghraoui, M., \& Reilinger, R. (2012). Onset of aseismic creep on major strikeslip faults. Geology, 40(12), 1115-1118. https://doi.org/10.1130/G33522.1

Carpenter, B. M., Marone, C., \& Saffer, D. M. (2011). Weakness of the San Andreas Fault revealed by samples from the active fault zone. Nature Geoscience, 4(4), 251-254. https://doi.org/10.1038/ngeo1089

Cetin, E., Cakir, Z., Meghraoui, M., Ergintav, S., \& Akoglu, A. M. (2014). Extent and distribution of aseismic slip on the Ismetpasa segment of the North Anatolian Fault (Turkey) from persistent scatterer InSAR. Geochemistry Geophysics Geosystems, 15, 2883-2894. https://doi. org/10.1002/2014GC005307

Champenois, J., Fruneau, B., Pathier, E., Deffontaines, B., Lin, K. C., \& Hu, J. C. (2012). Monitoring of active tectonic deformations in the Longitudinal Valley (Eastern Taiwan) using Persistent Scatterer InSAR method with ALOS PALSAR data. Earth and Planetary Science Letters, 337-338, 144-155. https://doi.org/10.1016/j.epsl.2012.05.025

De Michele, M., Raucoules, D., Rolandone, F., Briole, P., et al. (2011). Spatio-temporal evolution of surface creep in the Parkfield region of the San Andreas Fault (1993-2004) from synthetic aperture radar. Earth and Planetary Science Letters, 308(1-2), 141-150. https://doi. org/10.1016/j.epsl.2011.05.049

Deniz, R., Aksoy, A., Yalin, D., Seeger, H., \& Hirsch, O. (1993). Determination of crustal movement in Turkey by terrestrial geodetic methods. Journal of Geodynamics, 18(1-4), 13-22. https://doi.org/10.1016/0264-3707(93)90024-Z

Emre, O., Duman, T. Y., Ozalp, S., Elmaci, H., Olgun, S., \& Saroglu, F. (2013). Active fault map of Turkey with and explanatory text, Ankara, Turkey, Special Publication Series (Vol. 30). Ankara: General Directorate of Mineral Research and Exploration.

Eren, K. (1984). Strain analysis along the North Anatolian fault by using geodetic surveys. Bulletin Géodésique, 58(2), 137-150. https://doi. org/10.1007/BF02520898

Ergintav, S., McClusky, S., Hearn, E., Reilinger, R., Cakmak, R., Herring, T., et al. (2009). Seven years of postseismic deformation following the 1999, $M=7.4$ and $M=7.2$, Izmit, Düzce, Turkey earthquake sequence. Journal of Geophysical Research, 114, B07403. https://doi.org/ 10.1029/2008JB006021

Ergintav, S., Reilinger, R., Çakmak, R., Floyd, M., Cakir, Z., Dogan, U., et al. (2014). Istanbul's earthquake hot spots: Geodetic constraints on strain accumulation along faults in the Marmara seismic gap. Geophysical Research Letters, 41, 5783-5788. https://doi.org/10.1002/ 2014GL060985

Fattahi, H., \& Amelung, F. (2016). InSAR observations of strain accumulation and fault creep along the Chaman Fault system, Pakistan and Afghanistan. Geophysical Research Letters, 43, 8399-8406. https://doi.org/10.1002/2016GL070121

Ferretti, A., Prati, C., \& Rocca, F. (2001). Permanent scatterers in SAR interferometry. IEEE Transactions on Geoscience and Remote Sensing, 39(1), 8-20. https://doi.org/10.1109/36.898661

Fialko, Y. (2006). Interseismic strain accumulation and the earthquake potential on the southern San Andreas fault system. Nature, 441(7096), 968-971. https://doi.org/10.1038/nature04797

Foreman-Mackey, D., Hogg, D. W., Lang, D., \& Goodman, J. (2013). EMCEE: The MCMC hammer. Publications of the Astronomical Society of the Pacific, 125(925), 306-312. https://doi.org/10.1086/670067

Goodman, J., \& Weare, J. (2010). Ensemble samplers with affine invariance. Communications in Applied Mathematics and Computational Science, 5(1), 65-80. https://doi.org/10.2140/camcos.2010.5.65

Harris, R. A. (2017). Large earthquakes and creeping faults. Reviews of Geophysics, 55, 169-198. https://doi.org/10.1002/2016RG000539

Hayes, G. P., Furlong, K. P., Benz, H. M., \& Herman, M. W. (2014). Triggered aseismic slip adjacent to the 6 February 2013 Mw 8.0 Santa Cruz Islands megathrust earthquake. Earth and Planetary Science Letters, 388, 265-272. https://doi.org/10.1016/j.epsl.2013.11.010

Hearn, E. H., McClusky, S., Ergintav, S., \& Reilinger, R. E. (2009). Izmit earthquake postseismic deformation and dynamics of the north Anatolian Fault Zone. Journal of Geophysical Research, 114, B08405. https://doi.org/10.1029/2008JB006026

Herring, T. A., King, R. W., Floyd, M. A., \& McClusky, S. C. (2015). Introduction to GAMIT/GLOBK, release 10.6. Cambridge: Massachusetts Institute of Technology.

Hooper, A. (2008). A multi-temporal InSAR method incorporating both persistent scatterer and small baseline approaches. Geophysical Research Letters, 35, L16302. https://doi.org/10.1029/2008GL034654

Hooper, A., Bekaert, D., Spaans, K., \& Arıkan, M. (2012). Recent advances in SAR interferometry time series analysis for measuring crusta deformation. Tectonophysics, 514-517, 1-13. https://doi.org/10.1016/j.tecto.2011.10.013

Hubert-Ferrari, A., Barka, A., Jacques, E., Nalbant, S. S., Meyer, B., Armijo, R., et al. (2000). Seismic hazard in the Marmara sea region following the 17 August 1999 Izmit earthquake. Nature, 404(6775), 269-273. https://doi.org/10.1038/35005054

Hussain, E., Wright, T. J., Walters, R. J., Bekaert, D., Hooper, A., \& Houseman, G. A. (2016). Geodetic observations of postseismic creep in the decade after the 1999 Izmit earthquake, Turkey: Implications for a shallow slip deficit. Geophysical Research Letters, 121, 2980-3001. https://doi.org/10.1002/2015JB012737

Hussain, E., Wright, T. J., Walters, R. J., Bekaert, D. P., Lloyd, R., \& Hooper, A. (2018). Constant strain accumulation rate between major earthquakes on the North Anatolian Fault. Nature Communications, 9(1), 1392. https://doi.org/10.1038/s41467-018-03739-2

Jolivet, R., Candela, T., Lasserre, C., Renard, F., Klinger, Y., \& Doin, M. P. (2015). The burst-like behavior of aseismic slip on a rough fault: The creeping section of the Haiyuan Fault, China. Bulletin of the Seismological Society of America, 105(1), 480-488. https://doi.org/ $10.1785 / 0120140237$

Jolivet, R., Lasserre, C., Doin, M.-P., Guillaso, S., Peltzer, G., Dailu, R., \& Sun, J. (2012). Shallow creep on the Haiyuan fault (Gansu, China), revealed by SAR interferometry. Journal of Geophysical Research, 117, B06401. https://doi.org/10.1029/2011JB008732

Jolivet, R., Lasserre, C., Doin, M. P., Peltzer, G., Avouac, J. P., Sun, J., \& Dailu, R. (2013). Spatio-temporal evolution of aseismic slip along the Haiyuan fault, China: Implications for fault frictional properties. Earth and Planetary Science Letters, 377-378, 23-33. https://doi. org/10.1016/j.epsl.2013.07.020

Jolivet, R., Simons, M., Agram, P. S., Duputel, Z., \& Shen, Z.-K. (2015). Aseismic slip and seismogenic coupling along the Central San Andreas Fault. Geophysical Research Letters, 42, 297-306. https://doi.org/10.1002/2014GL062222

Jouanne, F., Audemard, F. A., Beck, C., Van Welden, A., Ollarves, R., \& Reinoza, C. (2011). Present-day deformation along the El Pilar Fault in eastern Venezuela: Evidence of creep along a major transform boundary. Journal of Geodynamics, 51(5), 398-410. https://doi. org/10.1016/j.jog.2010.11.003

Kaduri, M., Gratier, J., Renard, F., Cakir, Z., \& Lasserre, C. (2017). The implications of fault zone transformation on aseismic creep: Example of the North Anatolian Fault, Turkey. Journal of Geophysical Research: Solid Earth, 4208-4236. https://doi.org/10.1002/ 2016JB013803

Kaduri, M., Gratier, J.-P., Lasserre, C., Çakir, Z., \& Renard, F. (2018). Quantifying the partition between seismic and aseismic deformation along creeping and locked sections of the North Anatolian Fault, Turkey. Pure and Applied Geophysics. https://doi.org/10.1007/s00024018-2027-2 
Kampes, B. M., Hanssen, R. F., \& Perski, Z. (2003). Radar interferometry with public domain tools. In Proceedings of FRINGE, 3, December 2003.

Kaneko, Y., Fialko, Y., Sandwell, D. T., Tong, X., \& Furuya, M. (2013). Interseismic deformation and creep along the central section of the North Anatolian fault (Turkey): InSAR observations and implications for rate-and-state friction properties. Journal of Geophysical Research: Atmospheres, 118, 316-331. https://doi.org/10.1029/2012JB009661

Khoshmanesh, M., \& Shirzaei, M. (2018). Multiscale dynamics of aseismic slip on Central San Andreas Fault. Geophysical Research Letters, 45, 2274-2282. https://doi.org/10.1002/2018GL077017

Konca, A. O., LePrince, S., Avouac, J.-P., \& Helmberger, D. V. (2010). Rupture process of 1999, Mw 7.1 Düzce earthquake from joint analysis of SPOT, GPS, InSAR, strong-motion and teleseismic data: A supershear rupture with variable rupture velocity. Bulletin of the Seismological Society of America, 100(1), 267-287. https://doi.org/10.1785/0120090072

Lienkaemper, J. J., Galehouse, J. S., \& Simpson, R. W. (2001). Long-term monitoring of creep rate along the Hayward fault and evidence for a lasting creep response to 1989 Loma Prieta earthquake. Geophysical Research Letters, 28, 2269-2272. https://doi.org/10.1029/ 2000GL012776

Liu, Y., \& Lapusta, N. (2008). Transition of mode II cracks from sub-Rayleigh to intersonic speeds in the presence of favorable heterogeneity. Journal of the Mechanics and Physics of Solids, 56, 25-50. https://doi.org/10.1016/j.jmps.2007.06.005

Marone, C. (1998). Laboratory-derived friction laws and their application to seismic faulting. Annual Review of Earth and Planetary Sciences, 26(1), 643-696. https://doi.org/10.1146/annurev.earth.26.1.643

Maurer, J., \& Johnson, K. (2014). Fault coupling and potential for earthquakes on the creeping section of the Central San Andreas fault. Journal of Geophysical Research: Solid Earth, 119, 4414-4428. https://doi.org/10.1002/2013JB010741

Michel, R., \& Avouac, J. P. (2002). Deformation due to the 17 August 1999 Izmit, Turkey, earthquake measured from SPOT images. Journal of Geophysical Research, 107(B4), 2062. https://doi.org/10.1029/2000JB000102

Moore, D. E., \& Lockner, D. A. (2013). Chemical controls on fault behavior: Weakening of serpentinite sheared against quartz-bearing rocks and its significance for fault creep in the San Andreas system. Journal of Geophysical Research: Solid Earth, 118, 2558-2570. https:// doi.org/10.1002/jgrb.50140

Moore, D. E., \& Rymer, M. J. (2007). Talc-bearing serpentinite and the creeping section of the San Andreas Fault. Nature, 448(7155), 795-797. https://doi.org/10.1038/nature06064

Motagh, M., Hoffmann, J., Kampes, B., Baes, M., \& Zschau, J. (2007). Strain accumulation across the Gazikoy-Saros segment of the North Anatolian Fault inferred from Persistent Scatterer Interferometry and GPS measurements. Earth and Planetary Science Letters, 255(3-4), 432-444. https://doi.org/10.1016/j.epsl.2007.01.003

Nishimura, T., Matsuzawa, T., \& Obara, K. (2013). Detection of short-term slow slip events along the Nankai Trough, southwest Japan, using GNSS data. Journal of Geophysical Research: Solid Earth, 118, 3113-3125. https://doi.org/10.1002/jgrb.50222

Ozalaybey, O., Ergin, M., Aktar, M., Tapirdamaz, C., Bicmen, F., \& Yoruk, A. (2002). The 1999 Izmit earthquake sequence in Turkey: Seismological and tectonic aspects. Bulletin of the Seismological Society of America, 92(1), 337-386. https://doi.org/10.1785/0120000838 Ozener, H., Dogru, A., \& Turgut, B. (2012). Quantifying aseismic creep on the Ismetpasa segment of the North Anatolian Fault zone (Turkey) by 6 years of GPS observations. Journal of Geodynamics, 67(7), 72-77. https://doi.org/10.1016/j.jog.2012.08.002

Parsons, T. (2004). Recalculated probability of M7 earthquakes beneath the Sea of Marmara, Turkey. Journal of Geophysical Research, 109 , B05304. https://doi.org/10.1029/2003JB002667

Pousse-Beltram, L., Pathier, E., Jouanne, F., Vassallo, R., Reinoza, C., Audemard, F., et al. (2016). Spatial and temporal variations in creep rate along the El Pilar fault at the Caribbean-South American plate boundary (Venezuela), from InSAR. Journal of Geophysical Research: Solid Earth, 121, 8276-8296. https://doi.org/10.1002/2016JB013121

Reilinger, R. E., McClusky, S., Vernant, P., Lawrence, S., Ergintav, S., Cakmak, R., et al. (2006). GPS constraints on continental deformation in the Africa-Arabia-Eurasia continental collision zone and implications for the dynamics of plate interactions. Journal of Geophysical Research, 111, B05411. https://doi.org/10.1029/2005JB004051

Rousset, B., Jolivet, R., Simons, M., Lasserre, C., Riel, B., Milillo, P., et al. (2016). An aseismic slip transient on the North Anatolian Fault. Geophysical Research Letters, 43, 3254-3262. https://doi.org/10.1002/2016GL068250

Sandwell, D., Mellors, R., Tong, X., \& Wessel, P. (2011). GMTSAR: An InSAR processing system based on Generic Mapping Tools, technical report, Scripps Inst. Of Oceanogr., Univ. of Calif., San Diego, La Jolla. 12.

Savage, J. C. (1983). A dislocation model of strain accumulation and release at a subduction zone. Journal of Geophysical Research, 88(B6), 4984-4996.

Savage, J. C., \& Burford, R. O. (1973). Geodetic determination of relative plate motion in Central California. Journal of Geophysical Research, 78(5), 832-845. https://doi.org/10.1029/JB078i005p00832

Savage, J. C., \& Lisowski, M. (1993). Inferred depth of creep on the Hayward fault, central California. Journal of Geophysical Research, 98(B1), 787-793. https://doi.org/10.1029/92JB01871

Schmidt, D. A., Bürgmann, R., Nadeau, R. M., \& d'Alessio, M. A. (2005). Distribution of aseismic slip-rate on the Hayward fault inferred from seismic and geodetic data. Journal of Geophysical Research, 110, B08406. https://doi.org/10.1029/2004JB003397

Schmittbuhl, J., Karabulut, H., Lengliné, O., \& Bouchon, M. (2016). Long-lasting seismic repeaters in the central basin of the main Marmara fault. Geophysical Research Letters, 43, 9527-9534. https://doi.org/10.1002/2016GL070505

Stein, R. S., Barka, A., \& Dieterich, J. H. (1997). Progressive failure on the North Anatolian fault since 1939 by earthquake stress triggering. Geophysical Journal International, 128(3), 594-604. https://doi.org/10.1111/j.1365-246X.1997.tb05321.x

Steinbrugge, K. V., Zacher, E. G., Tocher, D., Whitten, C. A., \& Clair, C. N. (1960). Creep on the San Andreas Fault. Bulletin of the Seismological Society of America, 50, 396-404.

Thatcher, W. (1979). Systematic inversion of geodetic data in Central California. Journal of Geophysical Research, 84(B5), 2283-2297. https://doi.org/10.1029/JB084iB05p02283

Thomas, M. Y., Avouac, J. P., Champenois, J., Lee, J. C., \& Kuo, L. C. (2014). Spatio-temporal evolution of seismic and aseismic slip on the Longitudinal Valley Fault, Taiwan. Journal of Geophysical Research: Solid Earth, 119, 5114-5139. https://doi.org/10.1002/2013JB010603

Wang, L., Wang, R., Roth, F., Enescu, B., Hainzl, S., \& Ergintav, S. (2009). Afterslip and viscoelastic relaxation following the 1999 M7.4 Izmit earthquake from GPS measurements. Geophysical Journal International, 178(3), 1220-1237. https://doi.org/10.1111/j.1365246X.2009.04228.X

Wei, M., Sandwell, D., \& Fialko, Y. (2009). A silent M4.8 event of October 3-6, 2006, on the Superstition Hills Fault, Southern California Journal of Geophysical Research, 114, B07402. https://doi.org/10.1029/2008JB006135

Wright, T. J., Parsons, B. E., \& Lu, Z. (2004). Toward mapping surface deformation in three dimensions using InSAR. Geophysical Research Letters, 31, L01607. https://doi.org/10.1029/2003GL018827 